\title{
A systematic updated review of scientifically tested selected plants used for anxiety disorders
}

This article was published in the following Dove Press journal:

Botanics:Targets and Therapy

6 September 2012

Number of times this article has been viewed

\author{
Ashutosh Sharma \\ Alexandre Cardoso-Taketa \\ Griselda García \\ María Luisa Villarreal \\ Centro de Investigación en \\ Biotecnología, Universidad Autónoma \\ del Estado de Morelos, Cuernavaca, \\ Mexico
}

\begin{abstract}
The aim of this review is to provide a summary on multidisciplinary scientific information obtained from medicinal plants used worldwide to treat anxiety, focusing on pharmacological and clinical studies. The bibliographical investigation was carried out by consulting five peer-reviewed worldwide database publications for references, and patents. The information gathered on plants with attributed anxiolytic properties are presented as follows: (1) plant extracts with anxiolytic properties evaluated in animal models; (2) plants with clinical trials; (3) identified active compounds in plants that have been assayed in animal models; (4) mechanism of action of anxiolytic plant extracts and compounds; and (5) registered patents for anxiolytic plant preparations. We recorded 112 plant species belonging to 63 botanical families for which the anxiolytic properties had been tested in animal models. Eleven plant species to treat general anxiety disorders as well as eleven species to treat anxiety-associated conditions, had been documented by clinical trials. Thirty-three registers for active compounds belonging to five general types of secondary metabolites had also been recorded. The mechanism of action at the central nervous system level had been determined in 33 plant species, either in their extracts or isolated compounds. Forty-seven patent registrations for plant preparations to be used for the treatment of anxiety were included.
\end{abstract}

Keywords: anxiolytic compounds, anxiolytic extracts, clinical trials, patents, mechanism of action

\section{Introduction}

Anxiety disorders are considered to be a major cause of disability worldwide, and comprise generalized anxiety disorder and other commonly associated conditions, such as phobias, postmenopausal stress, post-traumatic syndrome, somatization and cognitive dysfunction, among others. Patients diagnosed with generalized anxiety disorder exhibit functional impairment as well as a tendency to develop comorbid psychiatric disorders. ${ }^{1}$ Effective treatments for this condition are usually focused on eliminating anxiety symptoms and restoring normal function. Conventional anxiolytic drug therapy is considered to be effective, safe, and broad-spectrum in action, ${ }^{2}$ but side effects often reduce quality of life, discouraging patients to follow medication protocols. Moreover, many of the medicines used for anxiety include antidepressants, and the use of such agents can cause troubling side effects, ie, cholinergic symptoms, weight gain, sleep disturbances, sexual dysfunction, medication dependence, or gastrointestinal problems.

The use of herbal remedies for the treatment of anxiety is an ancient practice that nowadays has become popular in Western societies. Plant-based medicines rep-
Correspondence: María Luisa Villarreal Centro de Investigación en Biotecnología, Universidad Autónoma del Estado de Morelos, Av Universidad I00I, Col Chamilpa, Cuernavaca, Morelos 62209, México Tel +52 7773297057 Fax +52 7773297030 Email luisav@uaem.mx 
resent the most popular treatment for an estimated $43 \%$ of the worldwide population that use complementary therapy to augment their treatment for anxiety disorders. ${ }^{3}$ It is also reported that anxiety disorders has become one of the most common reasons given for trying herbal medicines. ${ }^{4}$ However, despite their wide use, there is limited evidence for the efficacy of herbal products when observed in controlled clinical trials. In addition, many natural products are self-prescribed, and there is a lack of scientific evidence to confirm their potential benefits or to point out resulting disadvantages when they are used in combination with patented drugs, or even alone. For example, cases of liver toxicity resulting from use of Piper methysticum (kava) ${ }^{5}$ or of Hypericum perforatum, which can cause drug interactions, ${ }^{6}$ have been documented.

A synergistic effect resulting from the presence of various active compounds in one plant acting together to produce a greater effect than that expected from individual substances has been recognized and used in very ancient traditional medicinal practices as in Ayurvedic and Chinese medicine. ${ }^{7}$ This approach has now been accepted in modern phytotherapy, ${ }^{8}$ and the use of plant multidrug preparations is increasing to treat anxiety, depression, and other cognitive dysfunctions. ${ }^{9}$

\section{Methodology}

For this review, the indicated international literature was systematically searched to identify plants with anxiolytic effects that were documented in animal models. In addition, plant species employed in clinical trials to treat generalized anxiety disorder as well as related disorders were reviewed. We also present information about active compounds isolated from plants, and the mechanism of action of plant extracts or compounds. This review also incorporates a worldwide registry of plant patents used in the treatment of anxiety.

PubMed (MedLine), NAPRALERT, and EBSCO were the worldwide databases consulted without a time limit using the terms anxiolytic plant, anxiolytic extracts, antianxiety plants, herbal treatment for anxiety, clinical trials, general anxiety disorder, etc. The Espacenet database was used to locate patents from 1967 to the present using the terms plant, herbal, and extract, and cross-linking them with anxiety and anxiolytic terms. This search was corroborated using the USPTO database. More than 400 key publications for references were consulted. Plants used worldwide to treat anxiety and pharmacologically documented, as well as those used in clinical trials and cited in peer-reviewed international manuscripts, were included. Plants excluded were those empirically used in medicinal practices of anxiety, but without documented pharmacological or scientific studies. All sources utilized were written in English.

The publications that were included in the clinical studies were only those that were validated using the proper scale that measures the severity of anxiety, ie, the Hamilton anxiety (HAMA) scale, considered to be the gold-standard diagnostic tool.

\section{Plants with pharmacological anxiolytic effects}

From ancient times, medicinal plants were employed empirically, probably universally, for the treatment of anxiety and related disorders, but pharmacological and toxicological studies rarely existed. Even today, a relatively small number of these plants have been subjected to accepted scientific evaluation for their potential anxiolytic effects. Pharmacological studies with animal models are now used to test traditionally employed plants for their effectiveness in the treatment of anxiety-like behavior. Mice and rats present practical models for testing, due to their reproducibility, control of the inbreeding selection, and rapid response, as well as the possibility to analyze either brain structures or proteins and metabolites linked to the anxiety's phenotype. ${ }^{10,11}$ In the past, these animal models subjected to anxiety-producing substances were mainly assessed for their behavior using the hole-board and the light-dark transition tests, because these tests presented a pharmacological specificity where nonanxiolytic psychoactive drugs did not produce false positives. ${ }^{12}$ Nowadays, the elevated plus-maze (EPM) test is the model used to define the anxiolytic action of a plant extract in almost $80 \%$ of all scientific publications, followed by the light-dark transition ( 17\%), shock-probe burying ( 4\%), and hole-board ( 2\%) models. The EPM test was introduced by Pellow et al in 2005 employing rats, ${ }^{13}$ and by Lister in 1987 using mice. ${ }^{14}$ This model consists of two open and two enclosed arms, and is based on the natural aversion of rodents to open spaces, thereby avoiding exposure to threatening situations. The EPM test records the number of entries in both arms, where a higher percentage of time spent on the open arms indicates an anxiolytic effect. ${ }^{15}$

A total of 112 species belonging to 63 botanical families that had been subjected to in vivo animal models have been recorded in Table 1. The anxiolytic effects of these plants were determined using the EPM model conducted in mice in most of the species. As shown in Table 1, the Asteraceae, Fabaceae, and Lamiaceae families are the ones with a higher number of documented species. All the listed 
Table I Plants with pharmacological anxiolytic effect

\begin{tabular}{|c|c|c|}
\hline Family/species & $\begin{array}{l}\text { Countries/regions with } \\
\text { ethnobotanical use }\end{array}$ & References \\
\hline \multicolumn{3}{|l|}{ Acoraceae } \\
\hline Acorus calamus & India/China & 16 \\
\hline \multicolumn{3}{|l|}{ Aizoaceae } \\
\hline Sceletium tortuosum & South Africa & 17 \\
\hline \multicolumn{3}{|l|}{ Amaranthaceae } \\
\hline Achyranthes aspera & India & 18 \\
\hline \multicolumn{3}{|l|}{ Annonaceae } \\
\hline Rollinia mucosa & Mexico & 19 \\
\hline \multicolumn{3}{|l|}{ Apiaceae } \\
\hline Bupleurum falcatum & China & 20 \\
\hline Centella asiatica & India/China & 21 \\
\hline Coriandrum sativum & India/Iran & 22 \\
\hline \multicolumn{3}{|l|}{ Apocynaceae } \\
\hline Apocynum venetum & China & 23 \\
\hline Rauvolfia ligutrina & Brazil & 24 \\
\hline Tabernaemontana divaricata & India & 25 \\
\hline Tylophora indica & India & 26 \\
\hline \multicolumn{3}{|l|}{ Araceae } \\
\hline Colocasia esculenta & India & 27 \\
\hline \multicolumn{3}{|l|}{ Araliaceae } \\
\hline Panax ginseng & China & 28 \\
\hline Panax quinquefolium & China & 29 \\
\hline \multicolumn{3}{|l|}{ Asteraceae } \\
\hline Artemisia copa & Argentina & 30 \\
\hline Lactuca sativa & Egypt & 31 \\
\hline Matricaria recutita & Mexico & 32 \\
\hline Saussure alappan & India & 33 \\
\hline Sonchuso leraceus & Worldwide & 34 \\
\hline Sphaeranthus indicus & India & 35 \\
\hline Synedrella nodiflora & Ghana & 36 \\
\hline \multicolumn{3}{|l|}{ Boraginaceae } \\
\hline Echium amoenum & Iran & 37 \\
\hline \multicolumn{3}{|l|}{ Calophyllaceae } \\
\hline Kielmeyera coriacea & Brazil & 38 \\
\hline \multicolumn{3}{|l|}{ Clusiaceae } \\
\hline Garcinia kola & Africa & 39 \\
\hline \multicolumn{3}{|l|}{ Commelinaceae } \\
\hline Commelina benghalensis & China/Pakistan/India & 40 \\
\hline Palisota hirsuta & West Africa & 41 \\
\hline \multicolumn{3}{|l|}{ Convolvulaceae } \\
\hline Convolvulus pluricaulis & India & 42 \\
\hline Evolvulus alsinoides & India & 42 \\
\hline \multicolumn{3}{|l|}{ Elaeocarpaceae } \\
\hline Elaeocarpus sphaericus & India & 43 \\
\hline \multicolumn{3}{|l|}{ Equisetaceae } \\
\hline Equisetum arvense & Mexico/Italy & 44 \\
\hline \multicolumn{3}{|l|}{ Euphorbiaceae } \\
\hline Emblica officinalis & India & 45 \\
\hline Euphorbia hirta & Philippines & 46 \\
\hline \multicolumn{3}{|l|}{ Fabaceae } \\
\hline Albizia julibrissin & China & 47 \\
\hline Albizia lebbeck & India & 48 \\
\hline Astragalus mongholicus & China/Mongolia & 49 \\
\hline Bauhinia racemosa & India & 50 \\
\hline Caesalpinia bonducella & India/Africa & 51 \\
\hline Clitoria ternatea & India & 42 \\
\hline
\end{tabular}

(Continued)
Table I (Continued)

\begin{tabular}{|c|c|c|}
\hline Family/species & $\begin{array}{l}\text { Countries/regions with } \\
\text { ethnobotanical use }\end{array}$ & References \\
\hline Erythrina mulungu & Brazil & 52 \\
\hline Erythrina velutina & Brazil & 53 \\
\hline Glycyrrhiza glabra & India/China & 54 \\
\hline Griffonia simplicifolia & Not reported & 55 \\
\hline Sesbania grandiflora & India & 56 \\
\hline \multicolumn{3}{|l|}{ Gelsemiaceae } \\
\hline Gelsemium sempervirens & Mexico/US & 57 \\
\hline \multicolumn{3}{|l|}{ Gentianaceae } \\
\hline Canscora decussata & India & 58 \\
\hline Gentiana kochiana & Central/Northern Europe & 59 \\
\hline \multicolumn{3}{|l|}{ Ginkgoaceae } \\
\hline Ginkgo biloba & China & 60 \\
\hline \multicolumn{3}{|l|}{ Hypericaceae } \\
\hline Hypericum perforatum & Europe/North America & 61 \\
\hline \multicolumn{3}{|l|}{ Iridaceae } \\
\hline Crocus sativus & Iran/China/India & 62 \\
\hline \multicolumn{3}{|l|}{ Lamiaceae } \\
\hline Lavandula angustifolia & England/Europe & 63 \\
\hline Melissa officinalis & Europe & 64 \\
\hline Ocimum sanctum & India & 65 \\
\hline Salvia elegans & Mexico & 66 \\
\hline Salvia reuterana & Iran & 67 \\
\hline Scutellaria baicalensis & China & 68 \\
\hline Scutellaria lateriflora & North America & 69 \\
\hline Stachys lavanduifolia & Iran & 70 \\
\hline Vitex negundo & India & 71 \\
\hline \multicolumn{3}{|l|}{ Lauraceae } \\
\hline Cinnamomum cassia & China & 72 \\
\hline \multicolumn{3}{|l|}{ Lythraceae } \\
\hline Punica granatum & Worldwide & 73 \\
\hline \multicolumn{3}{|l|}{ Magnoliaceae } \\
\hline Schisandra chinensis & China & 74 \\
\hline \multicolumn{3}{|l|}{ Malpigeaceae } \\
\hline \multirow[t]{2}{*}{ Galphimia glauca } & Mexico & 75 \\
\hline & & 76 \\
\hline \multicolumn{3}{|l|}{ Malvaceae } \\
\hline Theobroma cacao & Not reported & 77 \\
\hline Tilia tomentosa & Latin America & 78 \\
\hline \multicolumn{3}{|l|}{ Meliaceae } \\
\hline Azadirachta indica & India & 79 \\
\hline \multicolumn{3}{|l|}{ Moraceae } \\
\hline Morus alba & China/India & 80 \\
\hline \multicolumn{3}{|l|}{ Myricaceae } \\
\hline Myrica nagi & India & 81 \\
\hline \multicolumn{3}{|l|}{ Nelumbonaceae } \\
\hline Nelumbo nucifera & India & 82 \\
\hline \multicolumn{3}{|l|}{ Nymphaeaceae } \\
\hline Nymphaea alba & Not reported & 83 \\
\hline \multicolumn{3}{|l|}{ Orchidaceae } \\
\hline Gastrodia elata & China & 84 \\
\hline \multicolumn{3}{|l|}{ Oxalidaceae } \\
\hline Oxalis corniculata & India & 85 \\
\hline Papaveraceae & & \\
\hline Eschsholzia californica & US & 86 \\
\hline Papilionaceae & & \\
\hline Trigonella foenumgraecum & India & 87 \\
\hline
\end{tabular}


Table I (Continued)

\begin{tabular}{|c|c|c|}
\hline Family/species & $\begin{array}{l}\text { Countries/regions with } \\
\text { ethnobotanical use }\end{array}$ & References \\
\hline \multicolumn{3}{|l|}{ Passifloraceae } \\
\hline Passiflora alata & Brazil & 88 \\
\hline Passiflora edulis & Brazil & 88 \\
\hline Passiflora incarnata & North America & 89 \\
\hline \multicolumn{3}{|l|}{ Phytolaccaceae } \\
\hline Hilleria latifolia & Ghana & 90 \\
\hline Petiveria alliacea & Brazil & 91 \\
\hline \multicolumn{3}{|l|}{ Pinaceae } \\
\hline Abies pindrow & India & 92 \\
\hline Cedrus deodara & India & 93 \\
\hline \multicolumn{3}{|l|}{ Piperaceae } \\
\hline Piper methysticum & North America & 94 \\
\hline \multicolumn{3}{|l|}{ Poaceae } \\
\hline Cymbopogon citratus & Brazil/India & 95 \\
\hline \multicolumn{3}{|l|}{ Polygalaceae } \\
\hline Securidaca longepedunculata & Africa & 96 \\
\hline \multicolumn{3}{|l|}{ Portulacaceae } \\
\hline Portulaca oleracea & China & 97 \\
\hline \multicolumn{3}{|l|}{ Rhamnaceae } \\
\hline Ziziphus jujuba & China & 98 \\
\hline \multicolumn{3}{|l|}{ Rosaceae } \\
\hline Crataegus oxycantha & India & 99 \\
\hline \multicolumn{3}{|l|}{ Rubiaceae } \\
\hline Gardenia jasminoides & Japan & 100 \\
\hline Morinda citrifolia & Worldwide & 101 \\
\hline Nauclea latifolia & Central Africa & 102 \\
\hline Uncaria rhynchophylla & China & 103 \\
\hline \multicolumn{3}{|l|}{ Rutaceae } \\
\hline Aeglemar melos & India & 104 \\
\hline Citrus aurantium & Brazil/Iran & 105 \\
\hline Glycosmis cochinchinensis & China & 106 \\
\hline Ruta chalepensis & Mexico & 107 \\
\hline \multicolumn{3}{|l|}{ Rosaceae } \\
\hline Rubus brasiliensis & Brazil & 108 \\
\hline \multicolumn{3}{|l|}{ Salisaceae } \\
\hline Salix aegyptiaca & Southeast Asia & 109 \\
\hline \multicolumn{3}{|l|}{ Sapindaceae } \\
\hline Cardiospermum halicacabum & India & 110 \\
\hline Paulina cupana & Brazil & III \\
\hline Sapindus mukorossi & India & 112 \\
\hline \multicolumn{3}{|l|}{ Scorphulariaceae } \\
\hline Bacopa monniera & India & 113 \\
\hline \multicolumn{3}{|l|}{ Simaroubaceae } \\
\hline Eurycoma longifolia & Indonesia/Malaysia & 114 \\
\hline \multicolumn{3}{|l|}{ Solanaceae } \\
\hline Withania somnifera & India & 115 \\
\hline \multicolumn{3}{|l|}{ Theaceae } \\
\hline Camellia sinensis & China/India & 116 \\
\hline \multicolumn{3}{|l|}{ Tiliaceae } \\
\hline Tilia americana & Mexico & 117 \\
\hline Turneraceae & & \\
\hline Turnera aphrodisiaca & India & 118 \\
\hline Urticaceae & & \\
\hline Cecropia glazioui & Latin America & 119 \\
\hline Valerianaceae & & \\
\hline Nordostchys jatamansi & India & 120 \\
\hline
\end{tabular}

Table I (Continued)

\begin{tabular}{lll}
\hline Family/species & $\begin{array}{l}\text { Countries/regions with } \\
\text { ethnobotanical use }\end{array}$ & References \\
\hline $\begin{array}{l}\text { Valeriana officinalis } \\
\text { Valeriana wallichii }\end{array}$ & $\begin{array}{l}\text { North America } \\
\text { Verbenaceae }\end{array}$ & 121 \\
$\begin{array}{l}\text { Aloysia polystachya } \\
\text { Vitaceae }\end{array}$ & Argentina & 122 \\
$\begin{array}{l}\text { Leea indica } \\
\text { Zinziberaceae }\end{array}$ & Bangladesh & 123 \\
Zingiber officinalis & South Asia & 125 \\
\hline
\end{tabular}

species have ethnomedical records in different countries, India (33.4\%) and China (16\%) being those with the most numerous citations.

\section{Human clinical studies with anxiolytic herbs}

Several herbal medicines with anxiolytic effects have been subjected to clinical trials. In Table 2A, plant species with documented use to treat general anxiety disorders are presented, while those used to treat anxiety-associated conditions are recorded in Table 2B. Table 2 shows clinical trials that used a validated scale measuring the severity of anxiety, ie, the HAMA scale, considered the gold-standard diagnostic tool. ${ }^{126}$ In addition, scales that measure how the patient is perceived symptomatologically by a physician are also included, as the Physician's Clinical Global Impression scale as well as the Clinical Global Impression-Improvement scale. These scales can measure the improvement of patients shown by reduction in the severity of symptoms. The randomness of the clinical trials is important for its reliability. The trials that were conducted using a contemporarily prescribed and accepted as effective antianxiety drug, indicated the level of effectiveness as related to the known anxiolytic drug, as well as permit a time evaluation as to the anxiolytic effects or the appearance of any adverse effects. With respect to the time of treatment and size of the sample, when compared with clinical trials with synthetic drugs - ie, such selective inhibitors of serotonin recapture as escitalopram and paroxetine, which represent first-line anxiolytic medicine as recommended by the World Federation of Societies of Biological Psychiatry, ${ }^{127}$ - the optimum time is 8 or more weeks, if we take into consideration that general anxiety disorder ideally requires a minimum treatment of two months and frequently more. Escitalopram has been studied for 10 weeks using a sample of 177 patients, ${ }^{128}$ and for 12 weeks with a sample of 150 patients. ${ }^{129}$ Paroxetine was studied for 8 weeks using 237 patients. ${ }^{130}$ It is 


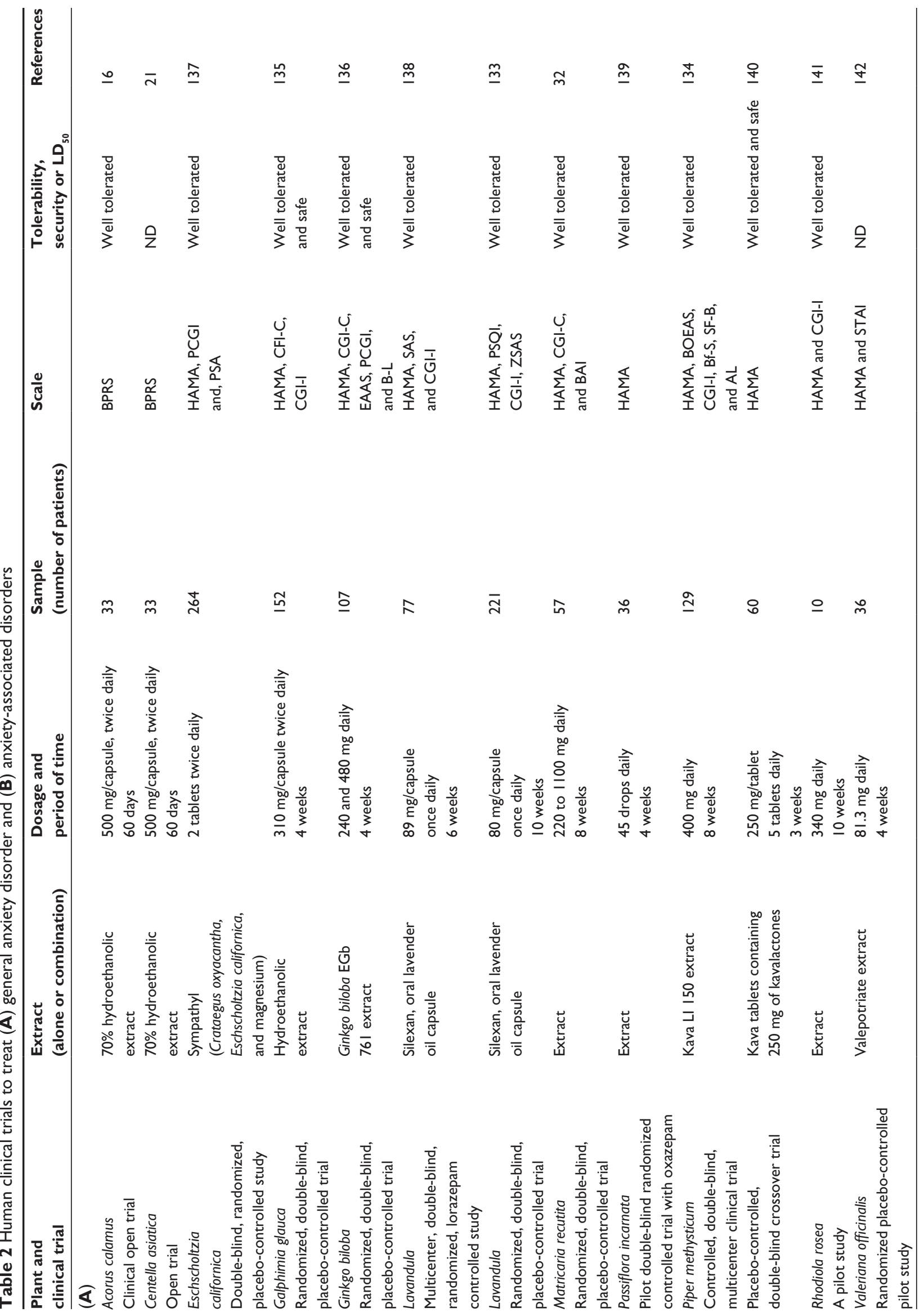




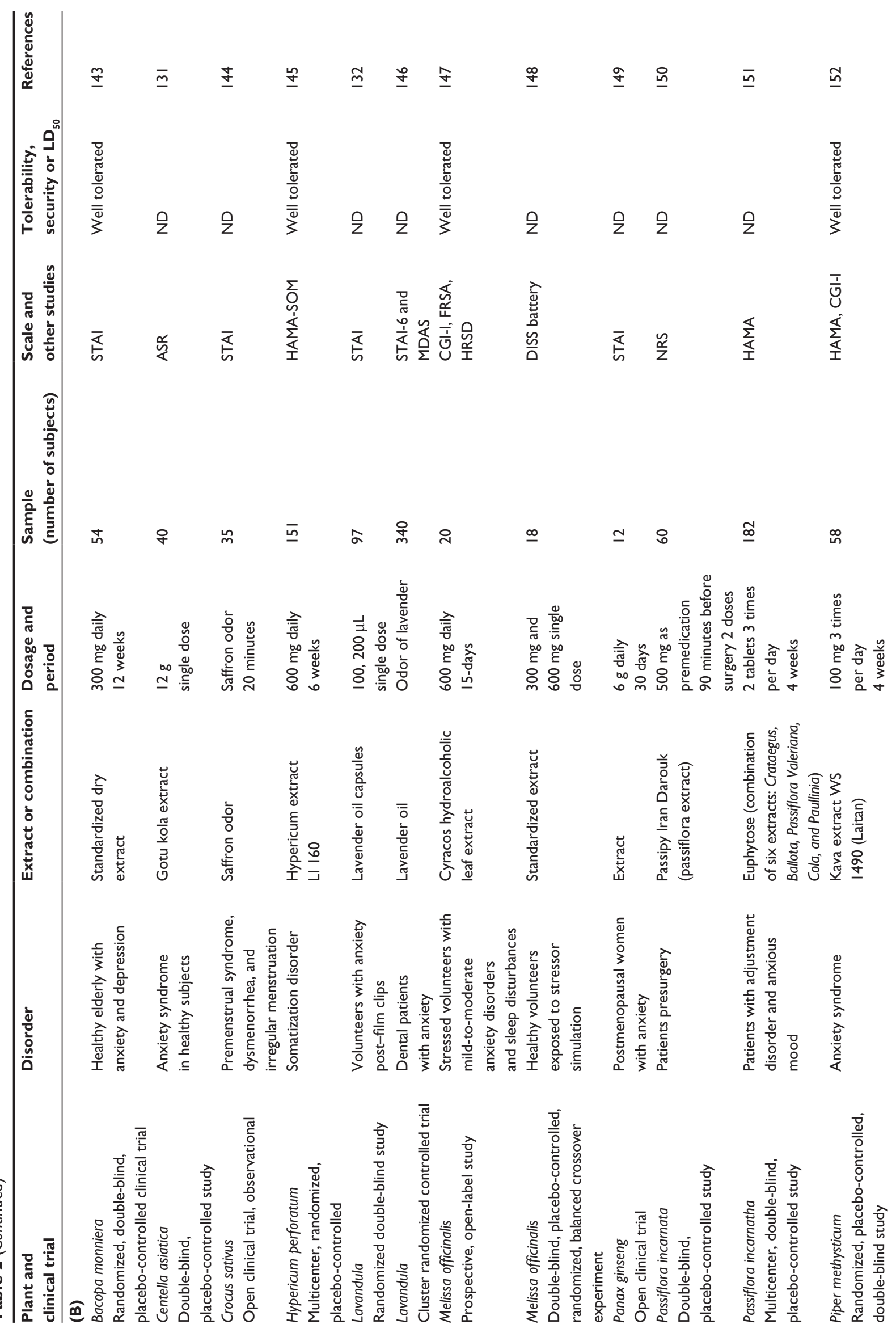




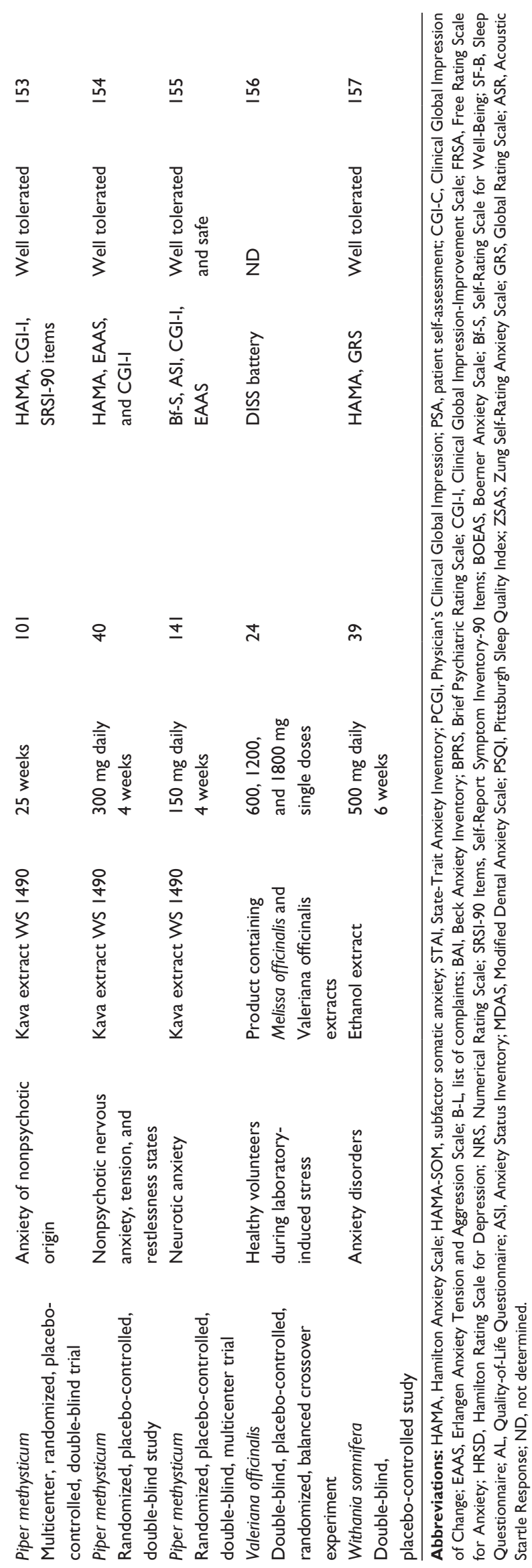

recommended that clinical trials using plants be performed with the same periods of time and using samples of more than 80 patients so as to be in line with the standards used for anxiolytic drugs. However, studies conducted with smaller groups can be useful as a guide for larger samples and for longer periods of medication. Most of the studies conducted with plants give tolerability data (absence or low frequency of adverse effects), allowing evaluation of the benefits of medicinal plants over such synthetic drugs as benzodiazepines and of inhibitors of serotonin recapture, both of which are the most prescribed anxiolytics. It is also important to conduct studies on children, teenagers and elderly patients. Table $2 \mathrm{~B}$ shows plants that reduce anxiety in conditions that differ from those of general anxiety disorders, and includes clinical trials using a scale to measure the severity of anxiety. Most clinical trials include small numbers, and in some cases, such as Centella asiatica ${ }^{131}$ or Lavandula spp. ${ }^{132}$ one dose is administered, which, if reduction of anxiety is reported, becomes preliminary data of the anxiolytic potential of the plants.

According to the aforementioned criteria, it is possible to consider rigorous studies such as the one with silexan oral lavender oil capsule conducted for 10 weeks in 221 patients, ${ }^{133}$ and the one with Piper methysticum conducted for 8 weeks with 129 patients, ${ }^{134}$ both having tolerability data. Two more studies reaching the required standards are those with Galphimia glauca conducted in 152 patients ${ }^{135}$ and with Ginkgo biloba ${ }^{136}$ in 107 patients, both including tolerability and security data.

\section{Active compounds}

A total of 33 purified natural compounds (Table 3) with proven anxiolytic activity were recorded from the 112 plants listed in Table 1. The reported compounds include a variety of secondary metabolites, ie, flavonoids, terpenoids, alkaloids, and phenols, with the terpenoids (total 14 compounds) forming the majority of the reported purified natural anxiolytic compounds ( $>42 \%$ ), and the flavonoids (nine compounds) forming the second major group. Other secondary metabolites such as alkaloids (five compounds), phenols (four compounds), and other derivatives were less reported.

\section{Mechanism of action}

From the literature, it is known that most of the herbal medicines that benefit anxiety disorders had effects on the gamma-aminobutyric acid (GABA) system. ${ }^{184}$ The reported mechanisms of action indicate the induction of ionic channel transmission blocking voltage gates or altering 
Table 3 Active compounds from anxiolytic plants

\begin{tabular}{|c|c|c|c|}
\hline Compound & Type of compound & Plant species & References \\
\hline I- $\alpha$-hydroxy-erythravine & Alkaloid & Erythrina mulungu & 158 \\
\hline 4-hyroxybenzaldehyde & Phenol & Gastrodia elata & 84 \\
\hline 4-hydroxybenzyl alcohol & Phenol & Gastrodia elata & 84 \\
\hline \multirow[t]{2}{*}{ 6-methylapigenin } & Flavonoid & Valeriana officinalis/Valeriana wallichii & 159 \\
\hline & & & 160 \\
\hline \multirow[t]{2}{*}{ Apigenin } & Flavonoid & Matricaria recutita/Turnera aphrodisiaca & 161 \\
\hline & & & 162 \\
\hline Bacoside A & Terpenoid & Bacopa monniera & 163 \\
\hline Baicalein & Flavonoid & Scutellaria baicalensis & 164 \\
\hline Baicalin & Flavonoid & Scutellaria lateriflora & 165 \\
\hline Cardiospermin & Cyanogenic-glucoside & Cardiospermum halicacabum & 110 \\
\hline Chrysin & Flavonoid & Passiflora incarnata & 166 \\
\hline Crocins & Terpenoid & Crocus sativus & 167 \\
\hline Dihydrokavain & Terpenoid & Piper methysticum & 168 \\
\hline Essential oil & Terpenoid & Citrus aurantiuman & 169 \\
\hline Essential oil & Terpenoid & Cymbopo goncitratus & 170 \\
\hline Erysothrine & Alkaloid & Erythrina mulungu & 171 \\
\hline Erythravine & Alkaloid & Erythrina mulungu & 158 \\
\hline Galphimines A-I & Terpenoid & Galphimia glauca & 172 \\
\hline Geniposide & Terpenoid & Gardeniae jasminoides & 100 \\
\hline Ginkgolic acid conjugates & Phenol & Ginkgo biloba & 173 \\
\hline Ginsenoside RbI & Terpenoid & Panax ginseng & 174 \\
\hline Ginsenosides $\mathrm{Rg} 3$ and $\mathrm{Rh} 2$ & Terpenoid & Panax ginseng & 175 \\
\hline Ginkgolide-A & Terpenoid & Ginkgo biloba & \\
\hline \multirow[t]{2}{*}{ Kaempferol } & Flavonoid & Apocynum venetum/Tilia americana & 176 \\
\hline & & & 177 \\
\hline Mangiferin & Phenol & Canscora decussata & 58 \\
\hline Neferine & Alkaloid & Nelumbo nucifera & 178 \\
\hline Quercetin & Flavonoid & Tilia americana & 177 \\
\hline Safranal & Terpenoid & Crocus sativus & \\
\hline Sanjoinine A & Alkaloid & Ziziphus jujube & 179 \\
\hline Seed oil & Terpenoid & Lactuca sativa & 180 \\
\hline Tiliroside & Flavonoid & Tilia americana & 181 \\
\hline Valepotriates & Terpenoid & Valeriana officinalis & 142 \\
\hline Valerenic acid & Terpenoid & Valeriana officinalis & 182 \\
\hline Wogonin & Flavonoid & Scutellaria baicalensis & 183 \\
\hline
\end{tabular}

membrane structures. ${ }^{185}$ GABA transaminase or glutamic acid decarboxylase inhibition has also been reported. ${ }^{186}$

In some cases, the herbal anxiolytic action was attributed to binding with benzodiazepine receptor sites (eg, $\alpha$-subunit). ${ }^{187}$ The increased GABA neurotransmission that subsequently followed had a damping effect on stimulatory pathways, which ultimately provided a psychologically calming effect. ${ }^{188}$ In Table 4, the mechanism of action of 33 extracts or purified compounds from herbal medicines to treat anxiety is detailed. This search was done for the 112 plants presented in Table 1 as well as for the compounds compiled in Table 3. A total of 33 plant extracts or purified compounds were identified in several databases. On the basis of the data in Table 4, it can be concluded that most of the plant extracts and purified anxiolytic compounds function through the GABAergic mechanism (more than 72\%, 24 total entries), and the rest (nine entries) utilize a combination of adrenergic, dopaminergic, and serotonergic mechanisms.

\section{Patent applications on plants with anxiolytic action}

A patent search was conducted using Espacenet database from the European Patent Office and corroborated by the United States Patent and Trademark Office (USPTO) database. The patent information covered the keywords plant, herbal, and extract, and these were cross-linked with anxiety and anxiolytic terms. Distillation of the final search resulted in a total of 47 patent applications for plants used as anxiolytic purposes. The adopted criteria used documentation written in English in which the anxiolytic activity was clearly demonstrated, and excluded those patents either without scientific backing or written in any language other 
Table 4 Mechanism of action of herbal anxiolytics extracts or compounds

\begin{tabular}{|c|c|c|c|}
\hline Plant species & Extract/compound & Mechanism of action & References \\
\hline Acorus calamus & Aqueous ethanol extract & Adrenergic and dopaminergic & 189 \\
\hline Albizzia lebbeck & $n$-Butanol fraction & GABAergic & 48 \\
\hline Albizzia julibrissin & Aqueous extract & Serotonergic & 47 \\
\hline \multirow[t]{2}{*}{ Aloysia polystachya } & Hydroethanol extract & Mediated by other mechanism than & 190 \\
\hline & & GABAa receptors & \\
\hline Apocynum venetum & Ethanol extract & GABAergic & 23 \\
\hline Bupleurum falcatum & Alcohol extract & Adrenergic mechanisms & 20 \\
\hline Cedrus deodara & Alcohol extract & GABAergic & 93 \\
\hline Convolvulus pluricaulis & Chloroform fraction of total ethanol extract & $\begin{array}{l}\text { Adrenergic, dopaminergic, } \\
\text { and serotonergic systems }\end{array}$ & 191 \\
\hline Cinnamomum cassia & Ethanol extract & Serotonergic and GABAergic & 72 \\
\hline Crataegus oxyacantha & Alcohol extract & GABAergic & 99 \\
\hline Cymbopogon citratus & Essential oil & GABAergic & 170 \\
\hline Erythrina velutina & Alcohol extract & GABAergic & 192 \\
\hline Gardeniae jasminoides & Standardized extract & GABAa & 193 \\
\hline Gastrodia elata & 4-Hyroxybenzaldehyde & GABAergic & 84 \\
\hline Gastrodia elata & 4-Hydroxybenzyl alcohol & Serotonergic & 84 \\
\hline Melissa officinalis & Cyracos standardized alcohol extract & GABAergic & 194 \\
\hline Morinda citrifolia & Methanol extract & GABAa & 101 \\
\hline Nelumbo nucifera & Aqueous extracts & GABAergic & 82 \\
\hline Palisota hirsuta & Ethanol extract & GABAergic & 41 \\
\hline Panax ginseng & Ginsenosides Rg3 and Rh2 & GABAergic & 175 \\
\hline Passiflora incarnata & Commercial extract & GABAergic & 195 \\
\hline Paulina cupana & Semipurified extract & Dopaminergic and serotonergic systems & 111 \\
\hline Piper methysticum & Ethanol extract & GABAa & 94 \\
\hline Rollinia mucosa & Hexane extract & GABA & 19 \\
\hline Rubus brasiliensis & Hexane extracts & GABAa & 108 \\
\hline Scutellaria ebaicalensis & Baicalein & GABAergic & 164 \\
\hline Scutellaria lateriflora & Baicalin & GABAa & 165 \\
\hline Scutellaria baicalensis & Wogonin & GABAa & 183 \\
\hline Ziziphus jujuba & Alcoholic extract & GABAergic & 196 \\
\hline Uncaria rhynchophylla & Aquous extract & Serotonergic & 103 \\
\hline Valeriana wallichii & 6-Methylapigenin & GABAa & 159 \\
\hline Valeriana officinalis & Valerenicacid & GABAa & 182 \\
\hline Ziziphus jujuba & Sanjoinine A & GABAergic & 179 \\
\hline
\end{tabular}

Abbreviation: GABA, gamma-aminobutyric acid.

than English. The first patent in this review was granted in 1967 by a Belgian company, in which the action of glaziovine, an alkaloid isolated from Ocotea, was registered to treat anxiety and depression. It is very difficult to obtain statistics for the global market involving the commercialization of anxiolytic plants and extracts, because most of the producers and exporters of such material come from underdeveloped countries where strict governmental control of data is lacking. The purpose of this review is to offer a record of the most important worldwide anxiolytic medicinal plants with high economic impact, as expressed by patent applications.

A total of 47 registered patent applications for anxiolytic plants were found. Of these, only seven were exclusively for the treatment of anxiety, while the rest reported medicinal use for additional disorders, basically for depression and stress. The four with the most patents are Valeriana officinalis, Piper methysticum (kava), Ziziphus jujuba (jujube), and Hypericum perforatum, each of which had five patents. Concerning these patents, 20 presented only one plant, 16 combined a mixture of other plants and isolated compounds, while six were for a plant mixed with purified compounds or extracts (Table 5).

The kava root presents an interesting case. Used in various Pacific Basin countries as a traditional beverage for soporific and narcotic effects, it was introduced into the US market in the 1990 s, principally as an antianxiety preparation. The bioactive kavalactones have been used for standardization in phytomedicines, acting very positively to decrease anxiety without the loss of mental acuity, as well as in dietary supplements. Although kava efficacy has been well established, in 2001 several fatal cases of hepatotoxicity among Westerners who consumed kava attracted the attention of the scientific community. The Food and Drug Administration (FDA) issued 


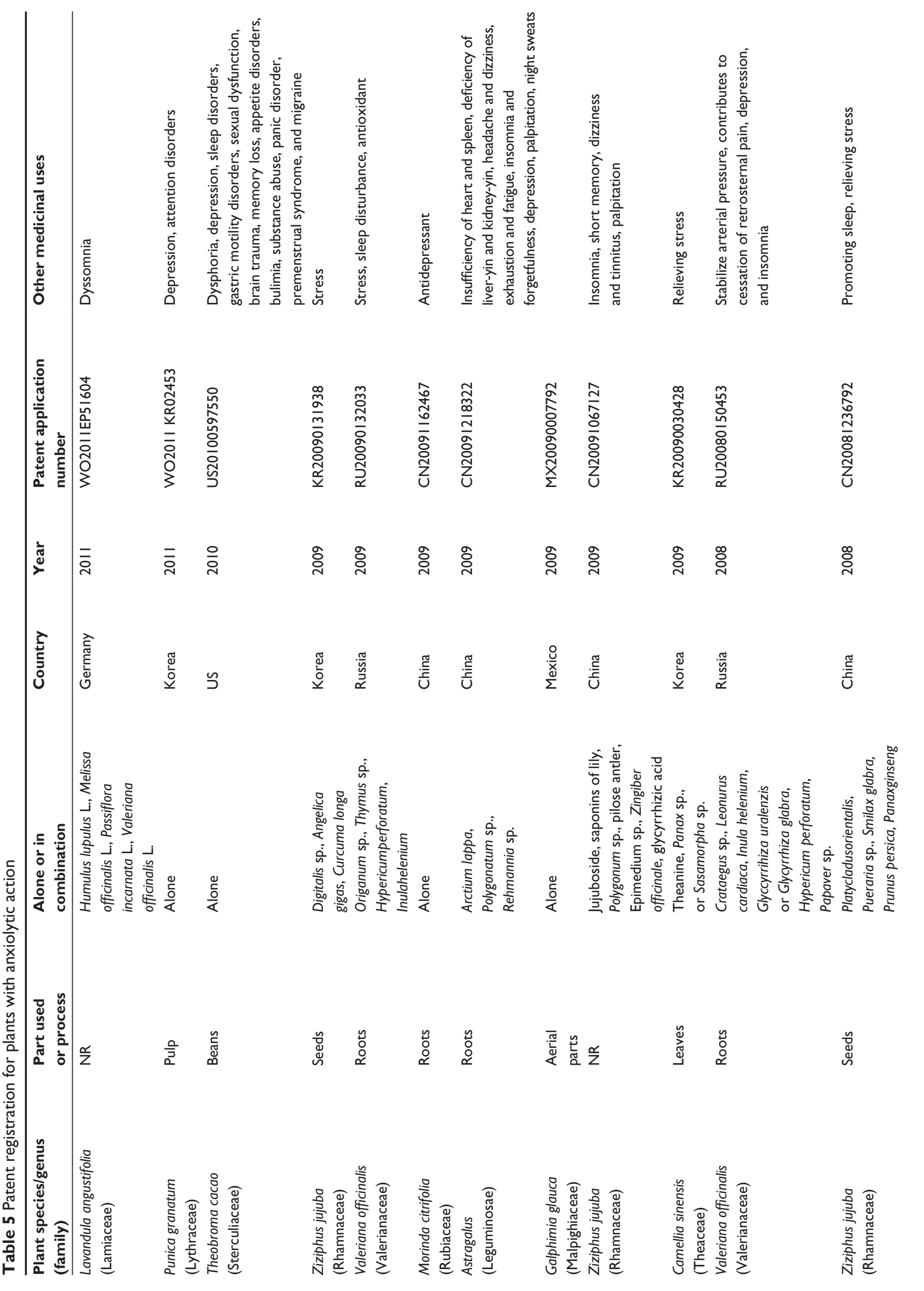



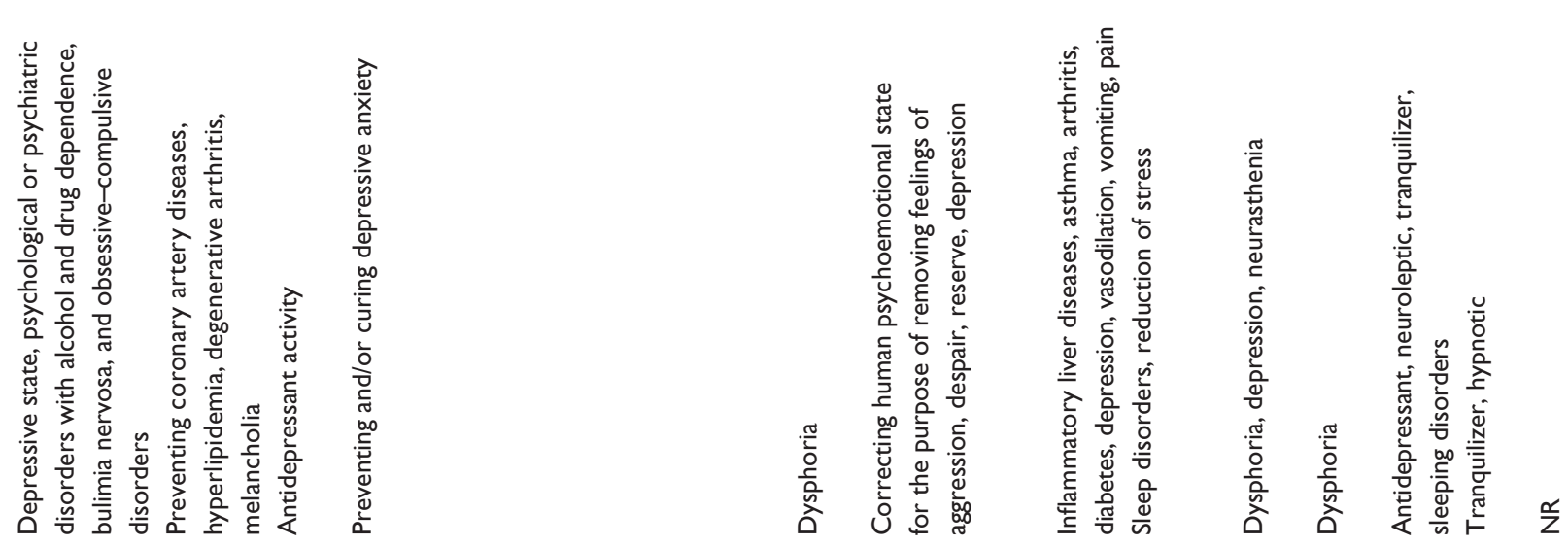

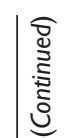
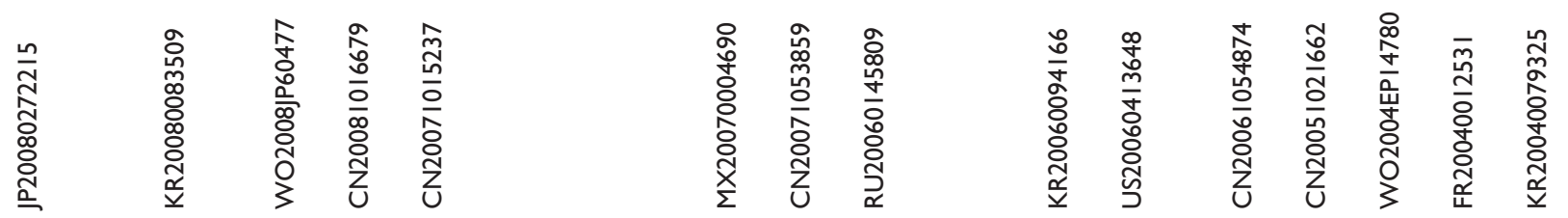

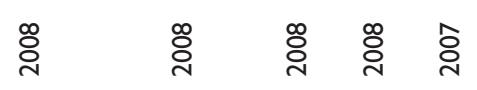

离总

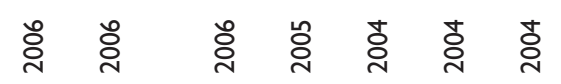

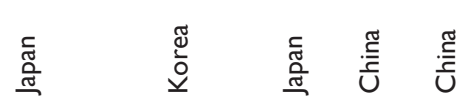

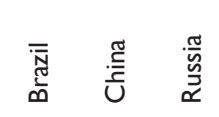

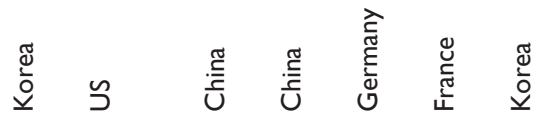

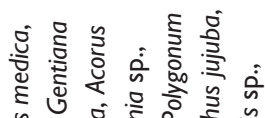

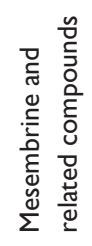

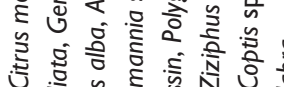

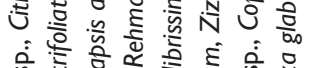

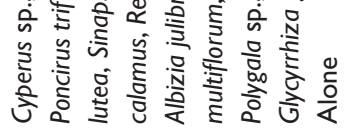

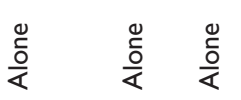

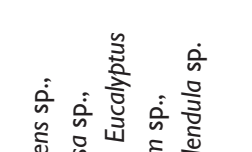

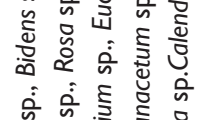

音

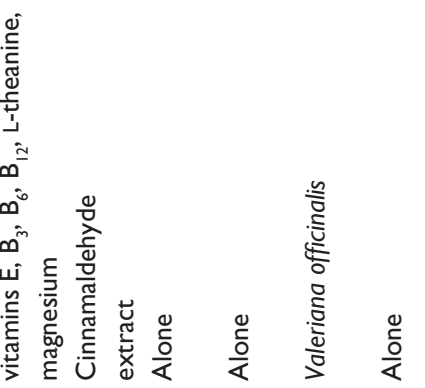

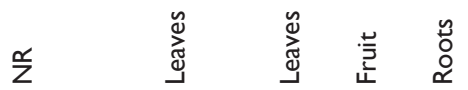

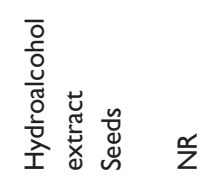

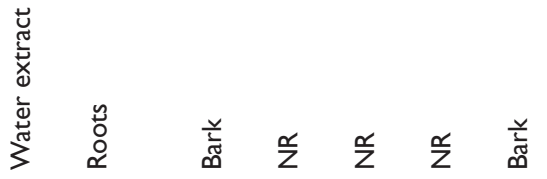

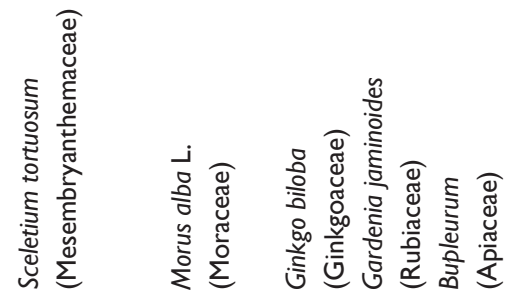
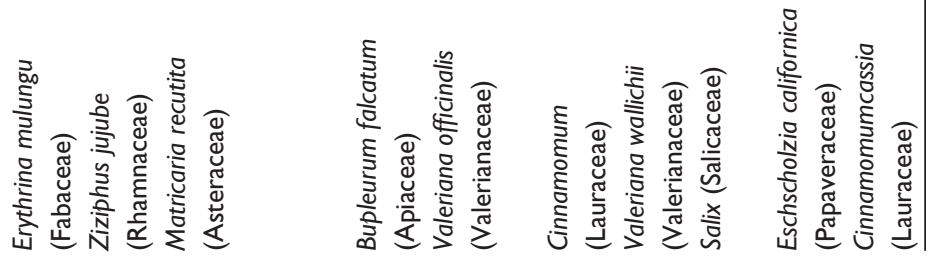


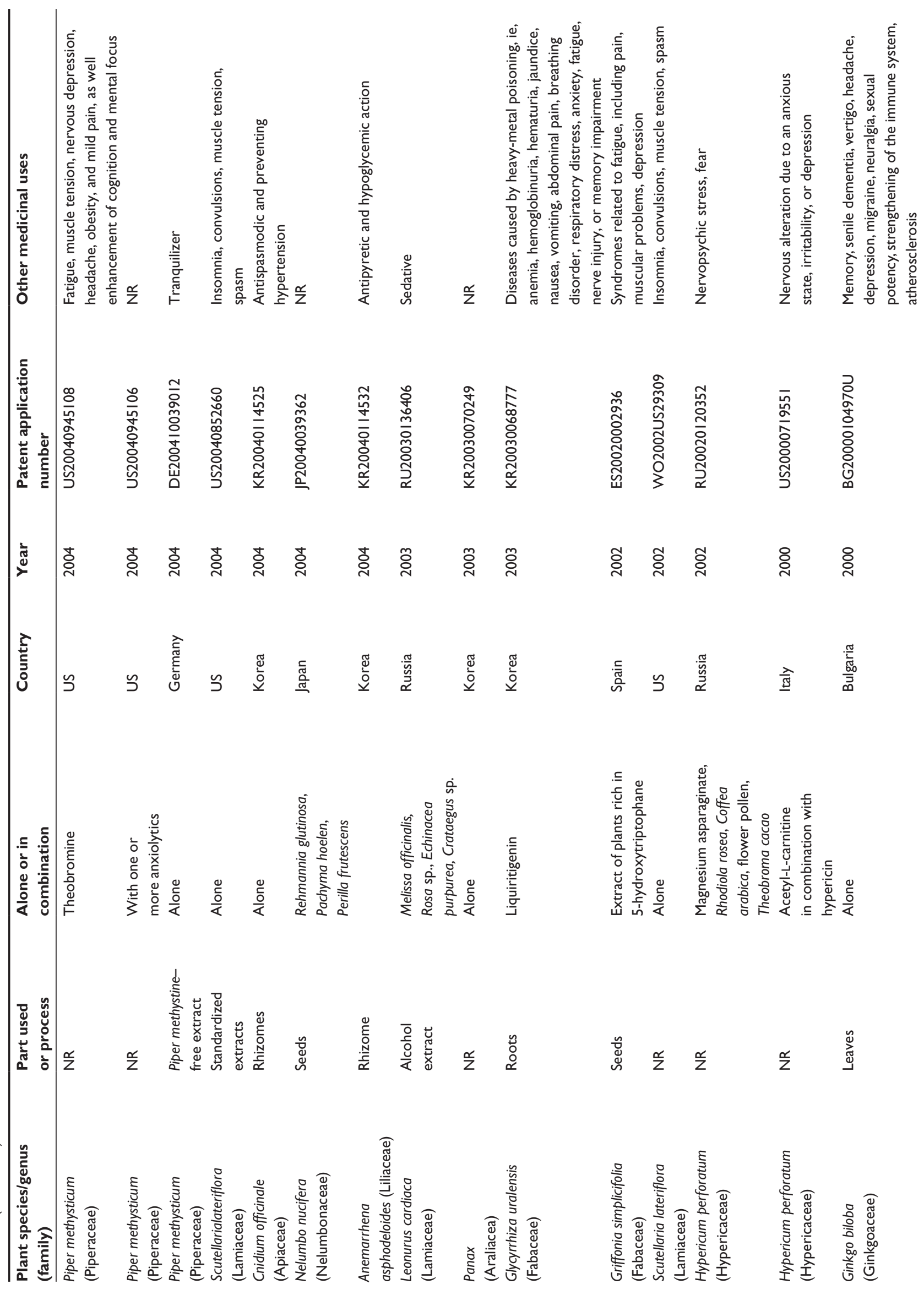


a customer advisory regarding the dangers of this agent in 2002. Its use is banned in several European countries. Nevertheless, a lot of doubts surround this issue because many data do not support a hepatotoxic potential, and the affected patients reported in the literature were also on other medications.

Although India possesses both an extraordinary flora and ancient knowledge based on the Ayurvedic legacy, it has no patent record in line with the criteria established. Three Indian patent applications, for Musa spp, Cassia tora, and Myristica fragrans, were excluded from our table because of a lack of scientific studies employing animals or clinical trials, despite a large body of ethnopharmacological evidence. However, a report in India indicated that 22 plants were patented for the treatment of brain and neurological disorders, occupying eighth position in the list of locally patented species, while the first position was for disorders of the digestive system, with a total of 81 species registered to $2005 .{ }^{197}$

Korea is the country with the most patent applications for anxiolytic plants, followed by China (Figure 1). Both countries have a long history of growing, using, and exporting traditional plant medicines. The number of stores and people involved in the trade of medicinal herbs has been growing through the centuries. After the opening of ports to Western trade, those in the traditional herbal medicines field faced the influx of Western medicines and secured their position in the plant trade by adapting a system of patenting the herbal remedies that they produced and sold. ${ }^{198}$

Both Brazil and Mexico have a megadiversity of flora and widespread traditional use of medicinal plants, and yet have only one patent application each. The analysis of the history of medicinal practices and uses in these two countries, with the lack of respect for indigenous knowledge, medicinal systems, and lack of official interests to establish priorities for the bioprospection of natural resources, combined with

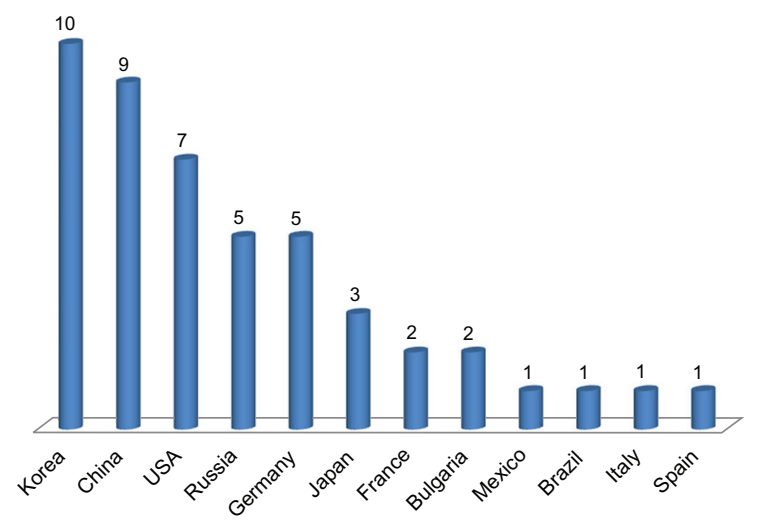

Figure I Number of species reported for anxiolytic uses in patents applied for by different countries. 
the imposition of allopathic medicines, go a long way towards explaining this situation.

Ethical discussions about biopiracy and the need to respect and protect indigenous and local community knowledge and biological resources, have emerged recently. Herbal drugs are gaining attention, mainly in developing countries due to their huge potential for new medicines, and focus is growing on patents because they contain formulations with multiherb composition, which have the potential to produce desired synergistic action with fewer deleterious side effects.

In spite of the high incidence and broad impact that anxiety has on the quality of human life, today there are no available laboratory tests to diagnose this worldwide health problem. Anxiety is usually diagnosed by means of psychological assessment criteria, interpreted by observation of the patient's behavior, taking into consideration his condition, historical background, and familial occurrences. Mental health professionals can make use of the Diagnostic and Statistical Manual of Mental Disorders, 4th edition, known as the DSM-IV, a manual published by the American Psychiatric Association with the aim of reaching a better understanding of the patient's illness and potential treatment.

Genetic factors associated with anxiety are complex and diverse. Advances in molecular biology techniques have allowed for the manipulation of gene expression within the central nervous system of mice in order to better understand the anxiety process at a molecular level. ${ }^{10}$ In future, individualized diagnosis and treatment for anxiety patients will be possible to prescribe based on patients' genetic profiling and on the levels of specific biomarkers through proteome and metabolome approaches. Therefore, it will be possible to know the real status of the biochemical routes involved in the pathology of anxiety, much beyond that provided by the monoamine systems. A breakthrough investigation was conducted by Filiou et al in 2011, ${ }^{11}$ in which they used endophenotype mice with a defined genetic background for high, normal, and low anxiety-related behaviors, and then compared them in terms of protein expression and presence of metabolites. The resulting proteomic and metabolomic information was combined and processed, and in silico analysis allowed for the identification of crucial metabolic networks responsible for anxiety response. They found altered levels of up to 300 proteins and metabolites between mice with high- and low-anxiety behavior, and highlighted the role of the mitochondria in modulating this action. Knowledge of mitochondrial influence in anxiety disorders is very limited. The authors proposed the mitochondria as the unifying link between energy metabolism, oxidative stress, and neurotransmission alterations observed for the anxiety behavior, indicating the mitochondria as a selective target in the development of new drugs to treat anxiety disorders.

\section{Conclusion}

Even though research is increasing in the area of psychopharmacology, until now no comprehensive review exists that explores the use of plants to treat anxiety disorders from various experimental approaches. Using a focused multidisciplinary context, as is presented here, which includes integrated information of in vivo pharmacological studies, as well as clinical trials and molecular targets, it becomes possible to obtain insights into this field and point out future directions. Although there exist several actual reported clinical trials that provide preliminary, positive evidence of anxiolytic effects, few rigorous studies of 8 weeks or more comparing the effect produced by plants with those obtained from the use of synthetic drugs are currently available. This situation clearly indicates that it is time to increase the number of experimental studies, and to conduct rigorous clinical trials with anxiolytic plants and their active compounds.

Moreover, there is still a need for scientifically based information concerning the safety, efficacy, and quality control in the use of anxiolytic plants. One example illustrating the need for quality control and analysis of toxicity is provided by the currently popular use of St John's wort. HIV patients are now told not to use this herbal remedy because it has been shown to create resistance to the currently approved HIV treatment.

This is the first review to offer a compilation of registered patents for anxiolytic plant preparations around the world. One observation on patents is that it would clearly be beneficial to include rigorous clinical trials. The use of the emerging "omics" technology can open a whole new efficient way of understanding the mechanism of action by which many plant extracts and their active compounds exert their pharmacological properties, and stimulate future research with anxiolytic herbal medicines.

\section{Disclosure}

The authors report no conflicts of interest in this work.

\section{References}

1. Wittchen HU, Zhao S, Kessler RC, Eaton WW. DSM III-R generalized anxiety disorder in the National Comorbidity Survey. Arch Gen Psychiatry. 1994;51(5):355-364.

2. Gorman JM. Treating generalized anxiety disorders. J Clin Psychiatry. 2003;64(2):24-29.

3. Astin JA. Why patients use alternative medicine: results of a national study. JAMA. 1998;279(19):1548-1553. 
4. Wong AHS, Smith M, Boon HS. Herbal medicines in psychiatric practice. Psychiatry. 1998;55(11):1033-1044.

5. Teschke R. Kava hepatotoxicity. A clinical review. Ann Hepatol. 2010;9(3):251-265.

6. Madabushi R, Frank B, Drewelow B, Derendorf H, Butterweck V. Hyperforin in St John's wort drug interactions. Eur J Clin Pharmacol. 2006;62(3):225-233.

7. Bensky D, Gambie A. Chinese Herbal Formulas. Seattle: Eastland Press; 1991.

8. Heinrich M, Barnes J, Gibbons S, Williamson E. Fundamentals of Pharmacognosy and Phytotherapy. London: Churchill Livingstone; 2004.

9. Sarris J, Panossian A, Schweitzer I, Stough C, Scholey A. Herbal medicine for depression, anxiety and insomnia: a review of psychopharmacology and clinical evidence. Eur Neuropsychopharmacol. 2011;21(12):841-860.

10. Gordon JA, Hen R. Genetic approaches to the study of anxiety. Annu Rev Neurosci. 2004;27:193-222.

11. Filiou MD, Zhang Y, Teplytska L, Reckow S, Gormanns P, Maccarrone G. Proteomics and metabolomics analysis of trait anxiety mouse model reveals divergent mitochondrial pathways. Biol Psychiatry. 2011;70(11):1074-1082.

12. Crawley JN. Exploratory behavior models of anxiety in mice. Neurosci Biobehav Rev.1985;9(1):37-44.

13. Pellow S, Chopin PH, File SE, Briley M. Validation of open:closed arm entries in an elevated plus-maze as a measure of anxiety in the rat. J Neurosci Methods. 1985;14(3):149-167.

14. Lister R. The use of a plus-maze to measure anxiety in the mouse Psychopharmacol. 1987;92(2):180-185.

15. Itoh J, Nabeshima $T$, Kameyama $T$. Utility of an elevated plusmaze for the evaluation of memory in mice: effects of nootropics, scopolamine and electroconvulsive shock. Psychopharmacology (Berl). 1990;101(1):27-33

16. Bhattacharyya D, Sur TK, Lyle N, Jana U, Debnath PK. A clinical study on the management of generalized anxiety disorder with Vaca (Acorus calamus). Indian J Tradit Knowl. 2011;10(4):668-671.

17. Smith C. The effects of Sceletium tortuosum in an in vivo model of psychological stress. J Ethnopharmacol. 2011;133(1):31-36.

18. Barua CC, Talukdar A, Begum SA, Borah P, Lahkar M. Anxiolytic activity of methanol leaf extract of Achyranthes aspera Linn in mice using experimental models of anxiety. Indian J Pharmacol. 2012;44(1):63-67.

19. Estrada-Reyes R, López-Rubalcava C, Rocha L, Heinze G, González-Esquinca AR, Martínez-Vázquez M. Anxiolytic-like and sedative actions of Rollinia mucosa: possible involvement of the GABA/benzodiazepine receptor complex. Pharm Biol. 2010;48(1): 70-75.

20. Lee B, Yun HY, Shim I, Lee H, Hahm DH. Bupleurum falcatum prevents depression and anxiety-like behaviors in rats exposed to repeated restraint stress. J Microbiol Biotechnol. 2012;22(3): 422-430.

21. Jana U, Sur TK, Maity LN, Debnath PK, Bhattacharyya D. A clinical study on the management of generalized anxiety disorder with Centella asiatica. Nepal Med Coll J. 2010;12(1):8-11.

22. Mahendra P, Bisht S. Anti-anxiety activity of Coriandrum sativum assessed using different experimental anxiety models. Indian J Pharmacol. 2011;43(5):574-577.

23. Grundmann O, Nakajima J, Seo S, Butterweck V. Anti-anxiety effects of Apocynum venetum $\mathrm{L}$. in the elevated plus maze test. J Ethnopharmacol. 2007;110(3):406-411.

24. Netto MS, Warela BWR, Fechine FM, Queiroga NM, QuintansJúnior JL. Anxiolytic-like effect of Rauvolfia ligustrina Willd. ex Roem. and Schult., Apocynaceae, in the elevated plus-maze and hole-board tests. Rev Bras Farmacogn. 2009;19(4):888-892.

25. Basavaraj P, Shivakumar B, Shivakumar H. Anxiolytic activity of Tabernaemontana divaricate (Linn) R. Br. Flowers extract in mice. Int $J$ Pharm Biosci. 2011;2(3):65-72.
26. Kulkarni PM, Archana R Juvekar. Effect of roots of Tylophora indica (Burm.f.) on stress and anxiety in animal models. Int J Pharm. 2010;8(2):1-5.

27. Kalariya M, Parmar S, Sheth N. Neuropharmacological activity of hydroalcoholic extract of leaves of Colocasia esculenta. Pharm Biol. 2010;48(11):1207-1212

28. Park JH, Cha HY, Seo JJ, Hong JT, Han K, Oh KW. Anxiolytic-like effects of ginseng in the elevated plus-maze model: comparison of red ginseng and sun ginseng. Prog Neuropsychopharmacol Biol Psychiatry. 2005;29(6):895-900.

29. Wei XY, Yang JY, Wang JH, Wu CF. Anxiolytic effect of saponins from Panax quinquefolium in mice. J Ethnopharmacol. 2007;111(3): 613-618.

30. Miño JH, Moscatelli V, Acevedo C, Ferraro G. Psychopharmacological effects of Artemisia copa aqueous extract in mice. Pharm Biol. 2010;48(12):1392-1396.

31. Hamed M, Assaf MH, Ahmed AS, Ahmed MS. Phytochemical and biological study of Lactuca sativa L. seeds growing in Egypt. Bull Fac Pharm Cairo Univ. 2003;41:239-252.

32. Amsterdam JD, Li Y, Soeller I, Rockwell K, Mao JJ, Shults J. A randomized, double-blind, placebo-controlled trial of oral Matricaria recutita (chamomile) extract therapy for generalized anxiety disorder. J Clin Psychopharmacol. 2009;29(4):378-382.

33. Shirishkumar DA, Mhetre AN, Patil MK, Desai T, Bodhankar LS. Anxiolytic activity of root extracts of Saussurea lappa in mice. $J$ Nat Remedies. 2006;6(2):103-108.

34. Cardoso-Vilela F, Soncini R, Giusti-Paiva A. Anxiolytic-like effect of Sonchus oleraceus L. in mice. J Ethnopharmacol. 2009;124(2):325-327.

35. Galani JV, Patel GB. Effect of hydroalcoholic extract of Sphaeranthus indicus against experimentally induced anxiety, depression and convulsions in rodents. Int J Ayurveda Res. 2010;1(2):87-92.

36. Woode E, Amoateng P, Abotsi WKM. Ethopharmacological analysis of the effects of the whole plant extract of Synedrella nodiflora (L.) Gaertn (Asteraceae) in murine models. Pharm Sin. 2011;2(2):54-67.

37. Rabbani M, Sajjadi SE, Vaseghi G, Jafarian A. Anxiolytic effects of Echium amoenum on the elevated plus-maze model of anxiety in mice. Fitoterapia. 2004;75(5):457-464.

38. Audi EA, Otobone F, Martins JV, Cortez DA. Preliminary evaluation of Kielmeyera coriacea leaves extract on the central nervous system. Fitoterapia. 2002;73(6):517-519.

39. Sunday AA, Nwoha PU. The use of elevated plus maze to study the effects of aqueous extract of Garcinia kola (Linn) on the anxiety status of malnourished mice. Electron J Biomed. 2011;2:63-67.

40. Raquibul Hasan SM, Hossain MM, Akter R, Jamila M, Mazumder EH, Rahman S. Sedative and anxiolytic effects of different fractions of the Commelina benghalensis Linn. Drug Discov Ther. 2009;3(5):221-227.

41. Woode E, Boakye-Gyasi E, Amidu N, Ansah C, Duwiejua M. Anxiolytic and antidepressant effects of a leaf extract of Palisota hirsuta K. Schum. (Commelinaceae) in mice. Int J Pharm. 2010;6(1):1-17.

42. Malik J, Karan M, Vasisht K. Nootropic, anxiolytic and CNS-depressant studies on different plant sources of shankhpushpi. Pharm Biol. 2011;49(12):1234-1242.

43. Shah G, Shri R, Mann A, Rahar S, Panchal V. Anxiolytic effects of Elaeocarpus sphaericus fruits on the elevated plus-maze model of anxiety in mice. Int J PharmTech Res. 2010;2(3):1781-1786.

44. Singh N, Kaur S, Bedi PM, Kaur D. Anxiolytic effects of Equisetum arvense Linn. extracts in mice. Indian J Exp Biol. 2011;49(5): 352-356.

45. Sudhakar P, Gopalakrishna HN, Swati B, Shreyasi C, Pai MRSM, Nair V. Antianxiety effect of aqueous extract of fruits of Emblica officinalis (EO) on acute and chronic administration in rats. J Pharm Res. 2010;3(2):219-223.

46. Lanhers MC, Fleurentin J, Cabalion P, et al. Behavioral effects of Euphorbia hirta L.: sedative and anxiolytic properties. J Ethnopharmacol. 1990;29(2):189-198. 
47. Kim WK, Jung JW, Ahn NY, Oh HR, et al. Anxiolytic-like effects of extracts from Albizzia julibrissin bark in the elevated plus-maze in rats. Life Sci. 2004;75(23):2787-2795.

48. Une HD, Sarveiya VP, Pal SC, Kasture VS, Kasture SB. Nootropic and anxiolytic activity of saponins of Albizzia lebbeck leaves. Pharmacol Biochem Behav. 2001;69(3-4):439-444.

49. Molodavkin GM, Aldarma ZH, Voronina TA, Dagatseren B. Behavioral and electrophysiological analysis of anxiolytic effect of Astragalus mongolicus. Bull Exp Biol Med. 1998;125(4):407-409.

50. Davey MS, Atlee C, Ashok Bharathi SRS, Farook M. Antianxiety effect of methanolic extract of Bauhinia racemosa (Lamk) stem bark in mice. Int J Pharm Biosci. 2011;2(2):217-224.

51. Altaf A, Venkat NR, Shalam M, Gouda TS, Mane BJ, Shantakumar SM. Anxiolytic activity of seed extract of Caesalpinia Bonducella (Roxb) in laboratory animals. Int J Pharm. 2008;5(2):1531-1537.

52. Onusic GM, Nogueira RL, Pereira AMS, Viana MB. Effect of acute treatment with a water alcohol extract from Erythrina mulungu on anxiety-related responses in rats. Braz J Med Biol Res. 2002;35: 473-477.

53. Raupp IM, Sereniki A, Virtuoso S, et al. Anxiolytic-like effect of chronic treatment with Erythrina velutina extract in the elevated plus-maze test. J Ethnopharmacol. 2008;118(2):295-299.

54. Ambawade SD, Kasture VS, Kasture SB. Anxiolytic activity of Glycyrrhiza glabra Linn. J Nat Remedies. 2001;2:130-134.

55. Carnevale G, Di Viesti V, Zavatti M, Zanoli P. Anxiolytic-like effect of Griffonia simplicifolia Baill. seed extract in rats. Phytomedicine. 2011;18(10):848-851.

56. Kasture VS, Deshmukh VK, Chopde CT. Anxiolytic and anticonvulsive activity of Sesbania grandiflora leaves in experimental animals. Phytother Res. 2002;16(5):455-460.

57. Dutt V, Dhar VJ, Sharma A. Antianxiety activity of Gelsemium sempervirens. Pharm Biol. 2010;48(10):1091-1096.

58. Sethiya KN, Nahata A, Dixit KV. Anxiolytic activity of Canscora decussata in albino rats. J Compl Integr Med. 2010;7(1):1-12.

59. Gordana T, Dijana K, Djurdjica SI, Branka BJ, Mirko DT. Anxiolyticlike effects of xanthone-rich diethylether extract of Gentiana kochiana in rodents. Dig J Nanomater Bios. 2011;6(3):1385-1392.

60. Kuribara H, Weintraub ST, Yoshihama T, Maruyama Y. An anxiolyticlike effect of Ginkgo biloba extract and its constituent, ginkgolide-A, in mice. J Nat Prod. 2003;66(10):1333-1337.

61. Flausino OA, Zangrossi H, Salgadoc JV, Vianaa MB. Effects of acute and chronic treatment with Hypericum perforatum L. (LI 160) on different anxiety-related responses in rats. Pharmachol Biochem Behav. 2002;71(1-2):251-257.

62. Hosseinzadeh H, Noraei NB. Anxiolytic and hypnotic effect of Crocus sativus aqueous extract and its constituents, crocin and safranal, in mice. Phytother Res. 2009;23(6):768-774.

63. Perry R, Terry R, Watson LK, Ernst E. Is lavender an anxiolytic drug? A systematic review of randomised clinical trials. Phytomedicine. 2012;19(8-9):825-835.

64. Taiwo EA, Leite BF, Lucena MG, et al. Anxiolytic and antidepressant-like effects of Melissa officinalis (lemon balm) extract in rats: influence of administration and gender. Indian $J$ Pharmacol. 2012;44(2):189-192.

65. Pemminati S, Swati B, Shreyasi C, Chandrasekhar R, Gopala Krishna HN, Pai MRSM. Anxiolytic activity of ethanolic extract of leaves of Ocimum sanctum in rats. Drug Invent Today. 2010;2(2): $115-118$.

66. Mora S, Millán R, Lungenstrass H, et al. The hydroalcoholic extract of Salvia elegans induces anxiolytic- and antidepressant-like effects in rats. J Ethnopharmacol. 2006;106(1):76-81.

67. Rabbani M, Sajjadi SE, Jafarian A, Vaseghi G. Anxiolytic effects of Salvia reuterana Boiss. on the elevated plus-maze model of anxiety in mice. J Ethnopharmacol. 2005;101(1-3):100-103.

68. Jung, JW, Ahn NY, Oh JK, Oh HR, Lee BK, Ryu JH. The anxiolyticlike effects of Scutellaria baicalensis using elevated plus-maze in rats. Korean J Pharmacogn. 2004;35(1):22-27.
69. Wolfson P, Hoffmann DL. An investigation into the efficacy of Scutellaria lateriflora in healthy volunteers. Altern Ther Health Med. 2003;9(2):74-78.

70. Rabbani M, Sajjadi SE, Zarei HR. Anxiolytic effects of Stachys lavandulifolia Vahl on the elevated plus-maze model of anxiety in mice. J Ethnopharmacol. 2003;89(2-3):271-276.

71. Adnaik RS, Pai PT, Sapakal VD, Naikwade NS, Magdum CS. Anxiolytic activity of Vitex negundo Linn. in experimental models of anxiety in mice. Int J Green Pharm. 2009;3(3):243-247.

72. Yu HS, Lee SY, Jang CG. Involvement of 5-HT1A and GABAA receptors in the anxiolytic-like effects of Cinnamomum cassia in mice. Pharmacol Biochem Behav. 2007;87(1):164-170.

73. Kumar S, Maheshwari KK, Singh V. Central nervous system activity of acute administration of ethanol extract of Punica granatum L. seeds in mice. Indian J Exp Biol. 2008;46(12):811-816.

74. Chen WW, He RR, Li YF, Li SB, Tsoi B, Kurihara H. Pharmacological studies on the anxiolytic effect of standardized Schisandra lignans extract on restraint-stressed mice. Phytomedicine. 2011;8(13):1144-1147.

75. Cardoso-Taketa AT, Pereda-Miranda R, Choi YH, Verpoorte R, Villarreal ML. Metabolic profiling of the Mexican anxiolytic and sedative plant Galphimia glauca using nuclear magnetic resonance spectroscopy and multivariate data analysis. Planta Med. 2008;74(10):1295-1301.

76. Sharma A, Cardoso-Taketa A, Choi YH, Verpoorte R, Villarreal ML. A comparison on the metabolic profiling of the Mexican anxiolytic and sedative plant Galphimia glauca four years later. J Ethnopharmacol. 2012;141(3):964-974.

77. Yamada T, Yamada Y, Okano Y, Terashima T, Yokogoshi H. Anxiolytic effects of short- and long-term administration of cacao mass on rat elevated T-maze test. J Nutr Biochem. 2009;20(12):948-955.

78. Viola $\mathrm{H}$, Wolfman $\mathrm{C}$, Levi de Stein $\mathrm{M}$, et al. Isolation of pharmacologically active benzodiazepine receptor ligands from Tilia tomentosa (Tiliaceae). J Ethnopharmacol. 1994;44(1):47-53.

79. Jaiswal AK, Bhattacharya SK, Acharya SB. Anxiolytic activity of Azadirachta indica leaf extract in rats. Indian J Exp Biol. 1994;32(7):489-491.

80. Yadav AV, Kawale LA, Nade VS. Effect of Morus alba L. (mulberry) leaves on anxiety in mice. Indian J Pharmacol. 2008;40(1):32-36.

81. Khan YM, Sagrawat H, Upmanyu N, Siddique S. Anxiolytic properties of Myrica nagi bark extract. Pharm Biol. 2008;46(10-11):757-761.

82. Mrugaya P Kulkarni, Archana R Juvekar. Anti-anxiety effects of leaves of Nelumbo nucifera Garen. in mice. Pharmacol Online. 2009;2:292-299.

83. Hippeswamy BS, Mishra B, Veerapur PV, Gupta G. Anxiolytic activity of Nymphaea alba Linn. in mice as experimental models of anxiety. Indian J Pharmacol. 2011;43(1):50-55.

84. Jung JW, Yoon BH, Oh HR, et al. Anxiolytic-like effects of Gastrodia elata and its phenolic constituents in mice. Biol Pharm Bull. 2006;29(2):261-265.

85. Sai Sampath T, Santosh P, Lahkar M, Ajaygodwin P, Pavan Kumar S, Lingesh A. Anxiolytic effect of ethanolic extract of Oxalis corniculata L in mice. Int J Pharm Bio Sci. 2011;2(3):281-290.

86. Rolland A, Fleurentin J, Lanhers MC, et al. Behavioural effects of the American traditional plant Eschscholzia californica: sedative and anxiolytic properties. Planta Med. 1991;57(3):212-216.

87. Dhananjaya DR, Vijay KS, Chandrashekar GP, Makhija IK, Shivakumara S. Anxiolytic activity of ethanolic extract of Trigonella foenumgraecum seeds. Arch App Sci Res. 2011;3(1):91-95.

88. Barbosa PR, Valvassori SS, Bordignon CL Jr, et al. The aqueous extracts of Passiflora alata and Passiflora edulis reduce anxiety-related behaviors without affecting memory process in rats. $J$ Med Food. 2008;11(2):282-288.

89. Grundmann O, Wähling C, Staiger C, Butterweck V. Anxiolytic effects of a passion flower (Passiflora incarnata L.) extract in the elevated plus maze in mice. Pharmazie. 2009;64(1):63-64.

90. Woode E, Abotsi WKM, Mensah AY. Anxiolytic- and antidepressantlike effects of an ethanolic extract of the aerial parts of Hilleria latifolia (Lam.) H. Walt. in mice. J Nat Pharm. 2011;2(2):62-71. 
91. Blainski A, Piccolo VK, Mello JCP, de Oliveira RMW. Dual effects of crude extracts obtained from Petiveria alliacea $\mathrm{L}$. (Phytolaccaceae) on experimental anxiety in mice. J Ethnopharmacol. 2010;128(2):541-544.

92. Kumar V, Singh RK, Jaiswal AK, Bhattacharya SK, Acharya SB. Anxiolytic activity of Indian Abies pindrow Royle leaves in rodents: an experimental study. Indian J Exp Biol. 2000;38(4): 343-346.

93. Dhayabaran D, Jeyaseeli Florance E, Nandakumar K, Puratchikody A. Anxiolytic and anticonvulsant activity of alcoholic extract of heart wood of Cedrus deodara Roxb. in rodents. $J$ Med Plant Res. 2010;4(14):1374-1381.

94. Garrett KM, Basmadjian G, Khan IA, Schaneberg BT, Seale TW. Extracts of kava (Piper methysticum) induce acute anxiolyticlike behavioral changes in mice. Psychopharmacology (Berl). 2003;170(1):33-41.

95. Shah G, Shiri R, Dhabiliya F, Nagpal N, Mann AS. Anti-anxiety activity of Cymbopogon citratus (DC.) stapf leaves extracts on the elevated plus-maze model of anxiety in mice. Pharmacogn $J$. 2010;2(15):45-50.

96. Adeyemi OO, Akindele AJ, Yemitan OK, Aigbe FR, Fagbo FI. Anticonvulsant, anxiolytic and sedative activities of the aqueous root extract of Securidaca longepedunculata Fresen. J Ethnopharmacol. 2010;130(2):191-195.

97. Miladi-Gorgi H, Vafaei AA, Rashidy-Pour A, Taherian AA, Jarrahi M, Emami-Abargoie M. Investigation of anxiolytic effects of the aqueous extract of Portulaca oleracea in mice. Iran J Pharm Res. 2004;165(3):57.

98. Peng HW, Hsieh TM, Lee SY, Lin CY, Liao J. Anxiolytic effect of seed of Ziziphus jujuba in mouse models of anxiety. $J$ Ethnopharmacol. 2000;72(3):435-441.

99. Arora A, Ashok M, Veera J, Radhakrishna B, Shivalinge KPG. Evaluation of anxiolytic activity of aqueous and alcoholic extracts of leaves of Crataegus oxycantha in mice. Int J Pharm Biomed Sci. 2011;2(3):86-91.

100. Toriizukaa K, Kamikia H, Ohmuraa YN, Fujiia M, Horia Y, Fukumura M. Anxiolytic effect of Gardeniae fructus-extract containing active ingredient from Kamishoyosan (KSS), a Japanese traditional Kampo medicine. Life Sci. 2005;77(24):3010-3020.

101. Deng S, West BJ, Palu AK, Zhou BN, Jensen CJ. Noni as an anxiolytic and sedative: a mechanism involving its gamma-aminobutyric acidergic effects. Phytomedicine. 2007;14(7-8):517-522.

102. Ngo-Bum E, Taiwe GS, Moto FC, et al. Anticonvulsant, anxiolytic, and sedative properties of the roots of Nauclea latifolia Smith in mice. Epilepsy Behav. 2009;15(4):434-440.

103. Jung JW, Ahn NY, Oh HR, et al. Anxiolytic effects of the aqueous extract of Uncaria rhynchophylla. J Ethnopharmacol. 2006;108(2):193-197.

104. Kothari S, Minda M, Tonpay SD. Anxiolytic and antidepressant activities of methanol extract of Aegle marmelos leaves in mice. Indian $J$ Physiol Pharmacol. 2010;54(4):318-328.

105. Jonaidi H, Abbasnejad M, Yousefi M. Anxiolytic effects of flower extracts from sour orange (Citrus aurantium L.) in rats. Psychopharmacol Biol Narcol. 2005;5(2):878-965.

106. Sravanthi V, Prashanth S, Anil Kumar A, Ramakrishna V, Govardhan P, Vidya Sagar J. Anxiolytic activity of Glycosmis cochinchinensis root in mice. J Pharm Res. 2011;4(9):3113-3115.

107. Gonzalez-Trujanoa ME, Carrera D, Ventura-Martinez R, CedilloPortugal E, Navarrete A. Neuropharmacological profile of an ethanol extract of Ruta chalepensis L. in mice. J Ethnopharmacol. 2006;106(1):129-135.

108. Nogueira E, Rosab GJM, Haraguchi M, Vassilieffa VS. Anxiolytic effect of Rubus brasilensis in rats and mice. J Ethnopharmacol. 1998;61(2):111-117.

109. Rabbani MS, Seyed E, Rahimi F. Anxiolytic effect of flowers of Salix aegyptiaca L. in mouse model of anxiety. J Compl Integ Med. 2010;7(1):1553-3840.
110. Kumar R, Murugananthan G, Nandakumar K, Talwar S. Isolation of anxiolytic principle from ethanolic root extract of Cardiospermum halicacabum. Phytomedicine. 2011;18(2-3):219-223.

111. Roncon CM, Biesdorf de Almeida C, Klein T, de Mello JC, Audi EA. Anxiolytic effects of a semipurified constituent of guaraná seeds on rats in the elevated T-maze test. Planta Med. 2011;77(3):236-241.

112. Chakraborty A, Amudha P, Geetha M, Singh SN. Evaluation of anxiolytic activity of methanolic extract of Sapindus Mukorossi Gaertn. in mice. Int J Pharm Bio Sci. 2010;1(3):1-8.

113. Chatterjee M, Verma P, Palit G. Comparative evaluation of Bacopa monniera and Panax quniquefolium in experimental anxiety and depressive models in mice. Indian J Exp Biol. 2010;48(3):306-313.

114. Ang HH, Cheang HS. Studies on the anxiolytic activity of Eurycoma longifolia Jack roots in mice. Jpn J Pharmacol. 1999;79(4):497-500.

115. Bhattacharya SK, Bhattacharya A, Sairam K, Ghosal S. Anxiolyticantidepressant activity of Withania somnifera glycol with anolides: an experimental study. Phytomedicine. 2000;7(6):463-469.

116. Mangal A, Jain V, Jain A, et al. Antianxiety activity of leaves of Camellia sinensis. J Pharm Res. 2010;3(3):605-607.

117. Pérez-Ortega G, Guevara-Fefer P, Chávez M, et al. Sedative and anxiolytic efficacy of Tilia americana var. mexicana inflorescences used traditionally by communities of state of Michoacan, Mexico. J Ethnopharmacol. 2008;116(3):461-468.

118. Kumar S, Sharma A. Apigenin: the anxiolytic constituent of Turnera aphrodisiaca. Pharm Biol. 2006;44(2):84-90.

119. Rocha FF, Lapa AJ, De Lima TC. Evaluation of the anxiolytic-like effects of Cecropia glazioui Sneth in mice. Pharmacol Biochem Behav. 2002;71(1-2):183-190.

120. Jadhav VM, Thorat RM, Kadam VJ, Kamble SS. Herbal anxiolyte: Nardostachys jatamansi. J Pharm Res. 2009;2(8):1208-1211.

121. Hattesohl M, Feistel B, Sievers H, Lehnfeld R, Hegger M, Winterhoff H. Extracts of Valeriana officinalis L. show anxiolytic and antidepressant effects but neither sedative nor myorelaxant properties. Phytomedicine. 2008;15(1-2):2-15.

122. Bhattacharyya D, Jana U, Debnath PK, Sur TK. Initial exploratory observational pharmacology of Valeriana wallichii on stress management: a clinical report. Nepal Med Coll J. 2007;9(1):36-39.

123. Mora S, Díaz-Véliz G, Millán R, et al. Anxiolytic and antidepressantlike effects of the hydroalcoholic extract from Aloysia polystachya in rats. Pharmacol Biochem Behav. 2005;82(2):373-378.

124. Raihan MO, Habib MR, Brishti A, Rahman MM, Saleheen MM, Manna M. Sedative and anxiolytic effects of the methanolic extract of Leea indica (Burm. f.) Merr. leaf. Drug Discov Ther. 2011;5(4):185-189.

125. Vishwakarma SL, Pal SC, Kasture VS, Kasture SB. Anxiolytic and antiemetic activity of Zingiber officinale. Phytother Res. 2002;16(7):621-626.

126. Hamilton MC. Diagnosis and rating of anxiety. $\mathrm{Br} J$ Psychiatry. 1969;3:76-79.

127. Bandelow B, Zohar J, Hollander E, Kasper S, Môller HJ. World Federation of Societies of Biological Psychiatry (WFSBP) guidelines for the pharmacological treatment of anxiety, obsessive-compulsive and post-traumatic stress disorders first revision. World J Biol Psychiatry. 2008;9:248-312.

128. Lenze EJ, Shear MK, Dew MA, et al. Escitalopram for older adults with generalized anxiety disorder. JAMA. 2009;301(3):295-303.

129. Lenze EJ, Goate AM, Nowotny P, et al. Relation of serotonin transporter genetic variation to efficacy of escitalopram for generalized anxiety disorder in older adults. J Clin Psychopharmacol. 2010;30(6):672-677.

130. Dubois O, Salamon R, Germain C, et al. Balneotherapy versus paroxetine in the treatment of generalized anxiety disorder. Complement Ther Med. 2010;18(1):1-7.

131. Bradwejn J, Zhou Y, Koszycki D, Shlik J. A double-blind, placebocontrolled study on the effects of Gotu Kola (Centella asiatica) on acoustic startle response in healthy subjects. J Clin Psychopharmacol. 2000;20(6):680-684. 
132. Bradley BF, Brown SL, Chu S, Lea RW. Effects of orally administered lavender essential oil on responses to anxiety-provoking film clips. Hum Psychopharmacol. 2009;24(4):319-330.

133. Kasper S, Gastpar M, Müller WE, et al. Silexan, an orally administered Lavandula oil preparation, is effective in the treatment of 'subsyndromal' anxiety disorder: a randomized, double-blind, placebo controlled trial. Int Clin Psychopharmacol. 2010;25(5):277-287.

134. Boerner RJ, Sommer H, Berger W, Kuhn U, Schmidt U, Mannel M. Kava-kava extract LI 150 is as effective as opipramol and buspirone in generalized anxiety disorder - an 8-week randomized, doubleblind multi-centre clinical trial in 129 out-patients. Phytomedicine. 2003;10(4):38-49.

135. Herrera-Arellano A, Jiménez-Ferrer E, Zamilpa A, Morales-Valdéz M, García-Valencia CE, Tortoriello J. Efficacy and tolerability of a standardized herbal product from Galphimia glauca on generalized anxiety disorder. A randomized, double-blind clinical trial controlled with lorazepam. Planta Med. 2007;73(8):707-713.

136. Woelk H, Arnoldt KH, Kieser M, Hoerr R. Ginkgo biloba special extract EGb 761 in generalized anxiety disorder and adjustment disorder with anxious mood: a randomized, double-blind, placebocontrolled trial. J Psychiatr Res. 2007;41(6):472-480.

137. Hanus M, Lafon J, Mathieu M. Double-blind, randomized, placebocontrolled study to evaluate the efficacy and safety of a fixed combination containing two plant extracts (Crataegus oxyacantha and Eschscholtzia californica) and magnesium in mild-to-moderate anxiety disorders. Curr Med Res Opin. 2004;20(1):63-71.

138. Woelk H, Schläfke S. A multi-center, double-blind, randomized study of the lavender oil preparation silexan in comparison to lorazepam for generalized anxiety disorder. Phytomedicine. 2010;17(2):94-99.

139. Akhondzadeh S, Naghavi HR, Vazirian M, Shayeganpour A, Rashidi H, Khani M. Passionflower in the treatment of generalized anxiety: a pilot double-blind randomized controlled trial with oxazepam. JClin Pharm Ther. 2001;26(5):363-367.

140. Sarris J, Kavanagh DJ, Byrne G, Bone KM, Adams J, Deed G. The Kava Anxiety Depression Spectrum Study (KADSS): a randomized, placebo-controlled crossover trial using an aqueous extract of Piper methysticum. Psychopharmacology (Berl). 2009;205(3):399-407.

141. Bystritsky A, Kerwin L, Feusner JD. A pilot study of Rhodiola rosea (Rhodax) for generalized anxiety disorder (GAD). J Altern Complement Med. 2008;14(2):175-180.

142. Andreatini R, Sartori VA, Seabra ML, Leite JR. Effect of valepotriates (valerian extract) in generalized anxiety disorder: a randomized placebo-controlled pilot study. Phytother Res. 2002;16(7):650-654.

143. Calabrese C, Gregory WL, Leo M, Kraemer D, Bone K, Oken B. Effects of a standardized Bacopa monnieri extract on cognitive performance, anxiety, and depression in the elderly: a randomized, double-blind, placebo-controlled trial. J Altern Complement Med. 2008;14(6):707-713

144. Fukui H, Toyoshima K, Komaki R. Psychological and neuroendocrinological effects of odor of saffron (Crocus sativus). Phytomedicine. 2011;18(8-9):726-730.

145. Volz HP, Murck H, Kasper S, Möller HJ. St John's wort extract (LI $160)$ in somatoform disorders: results of a placebo-controlled trial. Psychopharmacology (Berl). 2002;164(3):294-300.

146. Kritsidima M, Newton T, Asimakopoulou K. The effects of lavender scent on dental patient anxiety levels: a cluster randomized-controlled trial. Community Dent Oral Epidemiol. 2010;38(1):83-87.

147. Cases J, Ibarra A, Feuillère N, Roller M, Sukkar SG. Pilot trial of Melissa officinalis L. leaf extract in the treatment of volunteers suffering from mild-to-moderate anxiety disorders and sleep disturbances. Med J Nutrition Metab. 2011;4(3):211-218.

148. Kennedy DO, Little W, Scholey AB. Attenuation of laboratory-induced stress in humans after acute administration of Melissa officinalis (lemon balm). Psychosom Med. 2004;66(4):607-613.

149. Tode T, Kikuchi Y, Hirata J, Kita T, Nakata H, Nagata I. Effect of Korean red ginseng on psychological functions in patients with severe climacteric syndromes. Int J Gynaecol Obstet. 1999;67(3):169-174.
150. Movafegh A, Alizadeh R, Hajimohamadi F, Esfehani F, Nejatfar M. Preoperative oral Passiflora incarnata reduces anxiety in ambulatory surgery patients: a double-blind, placebo-controlled study. Anesth Analg. 2008;106(6):1728-1732.

151. Bourin M, Bougerol T, Guitton B, Broutin E. A combination of plant extracts in the treatment of outpatients with adjustment disorder with anxious mood: controlled study versus placebo. Fundam Clin Pharmacol. 1997;11(2):127-132.

152. Kinzler E, Krömer J, Lehmann E. Effect of a special kava extract in patients with anxiety-, tension-, and excitation states of nonpsychotic genesis. Double blind study with placebos over 4 weeks. Arzneimittelforschung. 1991;41(6):584-588.

153. Volz HP, Kieser M. Kava-kava extract WS 1490 versus placebo in anxiety disorders - a randomized placebo-controlled 25-week outpatient trial. Pharmacopsychiatry. 1997;30(1):1-5.

154. Malsch U, Kieser M. Efficacy of kava-kava in the treatment of nonpsychotic anxiety, following pretreatment with benzodiazepines. Psychopharmacology (Berl). 2001;157(3):277-283.

155. Gastpar M, Klimm HD. Treatment of anxiety, tension and restlessness states with Kava special extract WS 1490 in general practice: a randomized placebo-controlled double-blind multicenter trial. Phytomedicine. 2003;10(8):631-639.

156. Kennedy DO, Little W, Haskell CF, Scholey AB. Anxiolytic effects of a combination of Melissa officinalis and Valeriana officinalis during laboratory induced stress. Phytother Res. 2006;20(2):96-102.

157. Andrade C, Aswath A, Chaturvedi SK, Srinivasa M, Raguram R. A double-blind, placebo-controlled evaluation of the anxiolytic efficacy of an ethanolic extract of Withania somnifera. Indian $J$ Psychiatry. 2000;42(3):295-301.

158. Flausino OA Jr, Pereira AM, da Silva Bolzani V, Nunes-de-Souza RL. Effects of erythrinian alkaloids isolated from Erythrina mulungu (Papilionaceae) in mice submitted to animal models of anxiety. Biol Pharm Bull. 2007;30(2):375-378.

159. Wasowski C, Marder M, Viola H, Medina JH, Paladini AC. Isolation and identification of 6-methylapigenin, a competitive ligand for the brain GABA(A) receptors, from Valeriana wallichii. Planta Med. 2002;68(10):934-936.

160. Marder M, Viola H, Wasowski C, Fernández S, Medina JH, Paladini AC. 6-methylapigenin and hesperidin: new valeriana flavonoids with activity on the CNS. Pharmacol Biochem Behav. 2003;75(3):537-545.

161. 1Viola H, Wasowski C, Levi de Stein M, et al. Apigenin, a component of Matricaria recutita flowers, is a central benzodiazepine receptorsligand with anxiolytic effects. Planta Med. 1995;61(3):213-216.

162. Kumar S, Madaan R, Sharma A. Estimation of apigenin, an anxiolytic constituent, in Turnera aphrodisiaca. Indian J Pharm Sci. 2008;70(6):847-851.

163. Bhattacharya SK, Ghosal S. Anxiolytic activity of a standardized extract of Bacopa monniera: an experimental study. Phytomedicine. 2011;5(2):77-82.

164. De Carvalho RS, Duarte FS, De Lima TC. Involvement of GABAergic non-benzodiazepine sites in the anxiolytic-like and sedative effects of the flavonoid baicalein in mice. Behav Brain Res. 2011;221(1):75-82.

165. Awad R, Arnason JT, Trudeau V, et al. Phytochemical and biological analysis of skullcap (Scutellaria lateriflora L.): a medicinal plant with anxiolytic properties. Phytomedicine. 2003;10(8):640-649.

166. Brown E, Hurd NS, McCall S, Ceremuga TE. Evaluation of the anxiolytic effects of chrysin, a Passiflora incarnata extract, in the laboratory rat. $A A N A J$. 2007;75(5):333-337.

167. Pitsikas N, Boultadakis A, Georgiadou G, Tarantilis PA, Sakellaridis N. Effects of the active constituents of Crocus sativus L., crocins, in an animal model of anxiety. Phytomedicine. 2008;15(12):1135-1139.

168. Smith KK, Dharmaratne HR, Feltenstein MW, et al. Anxiolytic effects of kava extract and kavalactones in the chick social separation-stress paradigm. Psychopharmacology (Berl). 2001;155(1): 86-90. 
169. Carvalho-Freitas MI, Costa M. Anxiolytic and sedative effects of extracts and essential oil from Citrus aurantium L. Biol Pharm Bull. 2002;25(12):1629-1633.

170. Costa CA, Kohn DO, de Lima VM, Gargano AC, Flório JC, Costa M. The GABAergic system contributes to the anxiolytic-like effect of essential oil from Cymbopogon citratus (lemongrass). J Ethnopharmacol. 2011;137(1):828-836.

171. Santos Rosa D, Faggion SA, Gavin AS, et al. Erysothrine, an alkaloid extracted from flowers of Erythrina mulungu Mart. ex Benth: evaluating its anticonvulsant and anxiolytic potential. Epilepsy Behav. 2012;23(3):205-212.

172. Cardoso Taketa AT, Lozada-Lechuga J, Fragoso-Serrano M, Villarreal ML, Pereda-Miranda RJ. Isolation of nor-secofriedelanes from the sedative extracts of Galphimia glauca. Nat Prod. 2004;67(4):644-649.

173. Satyan KS, Jaiswal AK, Ghosal S, Bhattacharya SK. Anxiolytic activity of ginkgolic acid conjugates from Indian Ginkgo biloba. Psychopharmacology (Berl). 1998;136(2):148-152.

174. Carr MN, Bekku N, Yoshimura H. Identification of anxiolytic ingredients in ginseng root using the elevated plus-maze test in mice. Eur J Pharmacol. 2006;531(1-3):160-165.

175. Kim TW, Choi HJ, Kim NJ, Kim DH. Anxiolytic-like effects of ginsenosides Rg3 and Rh2 from red ginseng in the elevated plus-maze model. Planta Med. 2009;75(8):836-839.

176. Grundmann O, Nakajima J, Kamata K, Seo S, Butterweck V. Kaempferol from the leaves of Apocynum venetum possesses anxiolytic activities in the elevated plus maze test in mice. Phytomedicine. 2009; 16(4):295-302.

177. Aguirre-Hernández E, González-Trujano ME, Martínez AL, et al. HPLC/MS analysis and anxiolytic-like effect of quercetin and kaempferol flavonoids from Tilia americana var. mexicana. J Ethnopharmacol. 2010;127(1):91-97.

178. Sugimoto Y, Furutani S, Itoh A, et al. Effects of extracts and neferine from the embryo of Nelumbo nucifera seeds on the central nervous system. Phytomedicine. 2008;15(12):1117-1124.

179. Han H, MaY, Eun SJ, et al. Anxiolytic-like effects of sanjoinine A isolated from Zizyphi Spinosi Semen: possible involvement of GABAergic transmission. Pharmacol Biochem Behav. 2009;92(2):206-213.

180. Yakoot M, Helmy S, Fawal K. Pilot study of the efficacy and safety of lettuce seed oil in patients with sleep disorders. Int J Gen Med. 2011;4:451-456.

181. Herrera-Ruiz M, Román-Ramos R, Zamilpa A, Tortoriello J, JiménezFerrer JE. Flavonoids from Tilia americana with anxiolytic activity in plus-maze test. J Ethnopharmacol. 2008;118(2):312-317.

182. Murphy K, Kubin ZJ, Shepherd JN, Ettinger RH. Valeriana officinalis root extracts have potent anxiolytic effects in laboratory rats. Phytomedicine. 2010;17(8-9):674-678.

183. Hui KM, Huen MS, Wang HY, et al. Anxiolytic effect of wogonin, a benzodiazepine receptor ligand isolated from Scutellaria baicalensis Georgi. Biochem Pharmacol. 2002;64(9):1415-1424.
184. Sarris J. Herbal medicines in the treatment of psychiatric disorders: a systematic review. Phytother Res. 2007;21(8):703-716.

185. Sarris J, Kavanagh DJ. Kava and St John's wort: current evidence for use in mood and anxiety disorders. J Altern Complement Med. 2009;15(8):827-836.

186. Awad R, Levac D, Cybulska P, Merali Z, Trudeau VL, Arnason JT. Effects of traditionally used anxiolytic botanicals on enzymes of the gamma-aminobutyric acid (GABA) system. Can J Physiol Pharmacol. 2007;85(9):933-942.

187. Spinella M. The Psychopharmacology of Herbal Medicine: Plant Drugs That Alter Mind, Brain and Behaviour. Cambridge: MIT Press; 2001.

188. Baldwin DS, Polkinghorn C. Evidence-based pharmacotherapy of generalized anxiety disorder. Int J Neuropharm. 2005;8:293-302.

189. Bajaj DJ, Kaur P, Kishore H. Antidepressant-like effect of Acorus calamus Linn. and its possible mechanism in mice. Int J Pharm Recent Res. 2011;3(1):33-39.

190. Hellión-Ibarrola MC, Ibarrola DA, MontalbettiY, et al. The anxiolyticlike effects of Aloysia polystachya (Griseb.) Moldenke (Verbenaceae) in mice. J Ethnopharmacol. 2006;105(3):400-408.

191. Dhingra D, Valecha R. Evaluation of the antidepressant-like activity of Convolvulus pluricaulis Choisy in the mouse forced swim and tail suspension tests. Med Sci Monit. 2007;13(7):155-161.

192. Silva FT, Santos FN, Sarasqueta DFO, et al. Benzodiazepine-like effects of the alcohol extract from Erythrina velutina leaves: memory, anxiety, and epilepsy. Pharm Biol. 2008;46(5):321-328.

193. Toriizuka K, Hori Y, Fukumura M, Isoda S, Hirai Y, Ida Y. Investigation of the anxiolytic effects of Kampo formulation, Kamishoyosan, used for treating menopausal psychotic syndromes in women. Transm Mod Health Dis. 2009;4:183-189.

194. Ibarra A, Feuillere N, Roller M, Lesburgere E, Beracochea D. Effects of chronic administration of Melissa officinalis L. extract on anxietylike reactivity and on circadian and exploratory activities in mice. Phytomedicine. 2010;17(6):397-403.

195. Grundmann O, Wang J, McGregor GP, Butterweck V. Anxiolytic activity of a phytochemically characterized Passiflora incarnata extract is mediated via the GABAergic system. Planta Med. 2008;74(15):1769-1773.

196. Rong CL, Dai YX, Cui Y. Effects of Semen Ziziphi Spinosae on the anxiety behavior of the yin deficiency mice [Chinese]. Zhong Yao Cai. 2008;31(11):1703-1705.

197. Soam SK, Rashmi HB. Some reflections on patent search: a case study of medicinal plants of India. J Intellect Prop Rights. 2006;11:207-213.

198. Yang J. Modern medicine environment and adaptation of Korean trader for medicinal herbs from the late 19th century to the early 20th century [Korean]. Uisahak. 2006;15(2):189-209.
Botanics: Targets and Therapy

\section{Publish your work in this journal}

Botanics: Targets and Therapy is an international, peer-reviewed, open access journal focusing on the discovery and development of active compounds based upon or found naturally occurring in the plant kingdom that may have therapeutic potential in any disease state. The manuscript management system is completely online and includes a very

\section{Dovepress}

quick and fair peer-review system. Visit http://www.dovepress.com/ testimonials.php to read real quotes from published authors. 